\title{
The lampenflora in show caves and its treatment: an emerging ecological problem
}

\author{
Carlos Baquedano Estévez, Luis Moreno Merino*, Almudena de la Losa Román, \\ and Juan J. Durán Valsero
}

Instituto Geológico y Minero de España, C/Ríos Rosas 23, 28003 Madrid, Spain

\begin{abstract}
The artificial lighting of caves adapted for touristic visits, leads to the appearance and propagation of a complex community of phototrophic organisms known as "lampenflora". Formed mainly by algae and cyanobacteria, they produce the degradation of the colonized substrates and decrease the show value of the caves. This phenomenon became famous worldwide in the 1960s due to the damage caused to the paintings in the Lascaux Cave (France). Since then it has become an issue of serious concern to both managers of show caves and to the international scientific community. Over time, the problem has been approached following two complementary strategies: preventing colonization by the invading organisms or eliminating them once they have become established through the use of chemical products, mainly biocides and strong oxidants. This kind of treatment generates pollutant effluents that can move the problem from the walls of the caves to the groundwater. This paper presents a critical literature review of the problem and the proposed solutions, and emphasizes the need for further study of the optimal doses of treatment chemicals and to develop quantitative methods to determine their effectiveness.
\end{abstract}

Keywords: lampenflora, show caves, biofilms, biodeterioration, groundwater pollution

Received 3 April 2019; Revised 23 September 2019; Accepted 26 September 2019

Citation: Baquedano Estévez C., Moreno Merino L., de la Losa Román A. and Durán Valsero J.J., 2019. The lampenflora in show caves and its treatment: an emerging ecological problem. International Journal of Speleology, 48 (3), 249-277. Tampa, FL (USA) ISSN 0392-6672 https://doi.org/10.5038/1827-806X.48.3.2263

\section{INTRODUCTION}

Since prehistoric times, our ancestors have forged a special link with caves. They were initially used mainly for practical purposes as a temporary refuge or as spaces for permanent habitation, a source of water and certain minerals and even as places of worship and necropolises. Evidence of this early presence can be seen in the human remains found in numerous caves from the lower Pleistocene era through to the present day. Cave paintings are a special example of humans' close relationship with caves, of which some of the most spectacular are emblematic sites such as the Lascaux Cave and the Altamira Cave (Spain). Due to their outstanding natural and cultural importance, these caves, along with several dozen more such as the Las Manos Cave (Argentina), the Škocjan Caves (Slovenia) and the Mammoth Cave National Park (Kentucky, USA), are included on the list of World Heritage sites compiled by the UNESCO (United Nations Educational, Scientific and Cultural Organization).
In later centuries and until the present day, most caves have ceased to serve these functions; however, due to the natural beauty of their geological formations and their historic and cultural content, they have become a potent tourist attraction. In some cases, they also constitute a notable scientific resource, as many contain paleoenvironmental information and highly valuable geological records, such as is the case of the Nerja Cave (Spain) (Carrasco, 1993; Jordá Pardo et al., 2011).

Visiting caves is thought to be one of the oldest tourist experiences (Mulec \& Kosi, 2009). The concept of show cave (Cigna \& Forti, 2013) can be defined as "any cavity where a fee is paid to gain access and visit

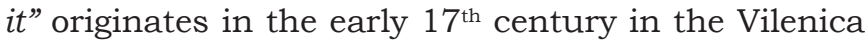
Cave (Slovenia), recognized since 1633 as the first show cave in the world; currently, practically every country in the world has at least one show cave.

It is estimated that there are around 500 large show caves worldwide with over 250 million visitors a year. If we include all the related activities (transport, accommodation, etc.), some 100 million people derive 
a direct or indirect income from this activity. Caves also provide income from speleotourism, religious tourism and even healthcare (Cigna \& Forti, 2013). The increase in these practices means this type of tourism has become an important economic resource which in certain areas represents the main source of income for its inhabitants (Cigna \& Burri, 2000; Bočić et al., 2006; Garofano \& Govoni, 2012).

For centuries, what is known as "underground tourism" was done in a very rudimentary way using torches or oil lamps as a source of illumination. Over time, some caves fashioned an artificial entrance from the outside, marked out a safer route on their interior, and gradually incorporated lighting equipment. Although these actions enhanced the observation and enjoyment of the caves, it also represented a very significant modification of the natural environmental conditions (Hoyos et al., 1998; Gillieson, 2011), casting light on areas that had remained in total darkness for millennia, increasing the environmental temperature and decreasing the relative humidity in their interior, as occurred for example in the Las Maravillas Cave (Spain) (Pulido-Bosch et al., 1997).

The degree of anthropic alteration of a show cave varies depending on the actions undertaken and the type of tourism practised (del Rosal, 2015). The impacts tend to be greater in caves adapted for general tourism than in caves adapted exclusively for scientific activity or the practice of speleotourism, with limited groups of participants who only require a speleological installation and a minimal portable lighting system.

The first caves equipped with electric lighting (Mulec \& Glažar, 2011) were the Luray Caverns (Virginia, USA) in 1881, followed by Kraushöhle (Austria) in 1883 and the Postojna Cave (Slovenia) in 1884. It was soon observed that the gradual installation of sources of artificial lighting inside the caves promoted the development and proliferation of a complex community of phototrophic organisms near the lamps. According to Cigna (2011a), this phenomenon was initially studied by Austrian (Kyrle, 1923; Morton \& Gams, 1925) and French (De Virville, 1928) scientists; and it was not until the 1960s when Dobat $(1963,1969)$ first introduced the word "lampenflora" (originally a German term coined in the English vocabulary) meaning "the flora of the lamps". This term is currently used internationally to identify this phenomenon, although it is also known as "mal verde" in Spanish or "maladie verte" in French (Lefèvre, 1974).

The issue of lampenflora is occasionally overlooked in show caves, where economic interests sometimes take precedence over conservation (Saiz-Jiménez, 2012). In certain caves (Mulec \& Glažar, 2011; Trinh $\&$ Garcia, 2013) the lampenflora is even displayed to visitors in a somewhat irresponsible way, when it is highlighted as a tourist attraction without the managers considering its removal, as is the case for example in Natural Bridge Caverns (Texas, USA) or in the karstic caves of the bay of Ha Long (Vietnam).

However, lampenflora poses a serious problem, as it constitutes an invasive and opportunistic community in anthropized underground environments. This is because, with the exception of the cave entrance, these organisms use artificial light to develop and therefore grow in places where they would not occur naturally (Mulec, 2012). In addition, the new inhabitants of the caves that have developed thanks to artificial lighting compete successfully to occupy this ecological niche. The problem is aggravated in many caves, because the sites of greatest interest to tourists (cave paintings or high-value geological formations) tend to be better illuminated than the rest of the cave. This increases its attractiveness to the public, but means these areas are more likely to be colonized by lampenflora.

In recent decades numerous works have been published on lampenflora communities in the international scientific literature, and on the methods that have been used to prevent and control their growth in caves. This work is a review of the state of the art in the methods of lampenflora control and their pros and cons. Figure 1 shows a map of the locations of the caves mentioned in this work and offers an overview of their geographic distribution. Table 1 contains a list of the caves mentioned, and a brief summary of some of their most important features.

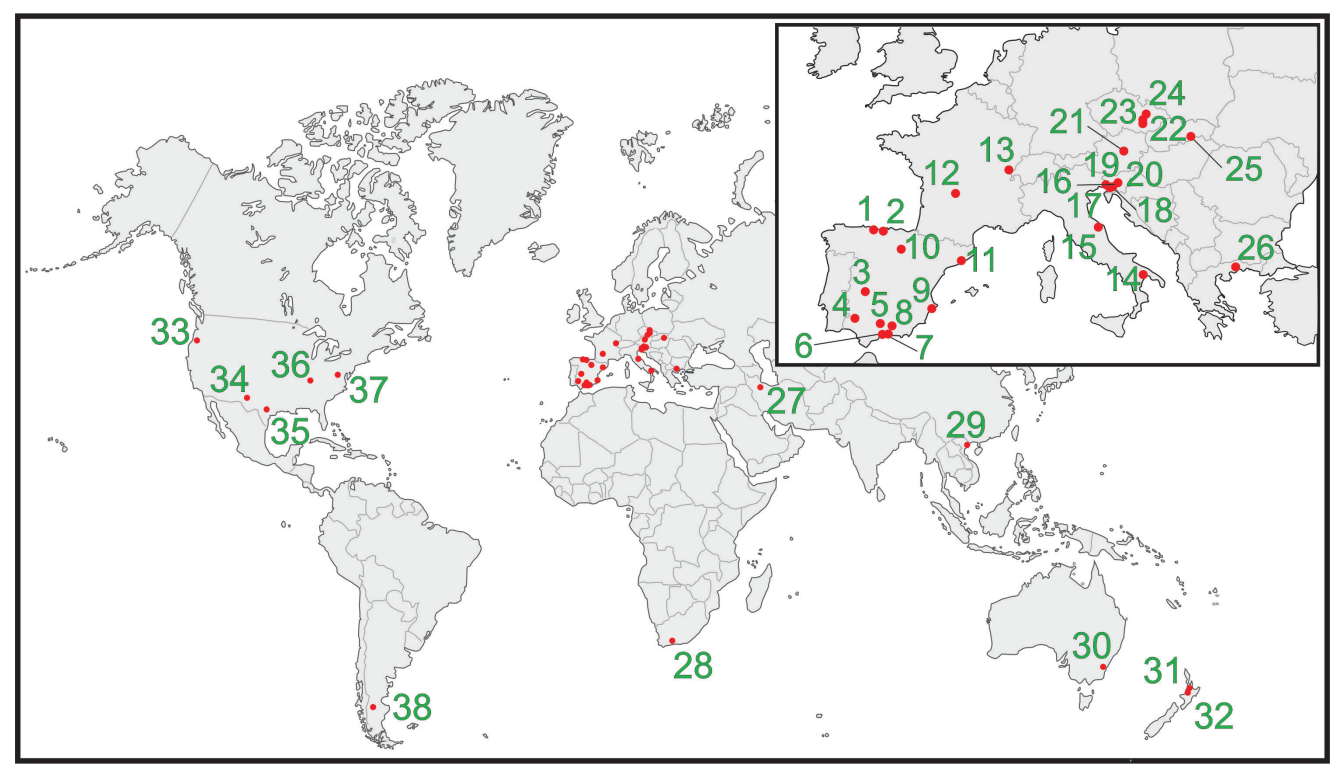

Fig. 1. Geographic distribution of the caves mentioned in this work. Numbers represent the caves in Table 1. 
Table 1. Caves mentioned in this work and a brief summary of their most important characteristics

\begin{tabular}{|c|c|c|c|}
\hline & Name & Country & Characteristics \\
\hline 1 & Tito Bustillo Cave & Spain & $\begin{array}{c}\text { Cave with prehistoric paintings included on UNESCO's World Heritage list since } 2008 \text { in } \\
\text { the category of "Palaeolithic rock art of northern Spain". The development of lampenflora } \\
\text { posed a serious problem and led to the closure of cave. }\end{array}$ \\
\hline 2 & Altamira Cave & Spain & $\begin{array}{l}\text { Declared a World Heritage site by the UNESCO in 1985, it contains one of the } \\
\text { most extraordinary manifestations of Palaeolithic art in the world. The growth of } \\
\text { photosynthetic microorganisms led to the closure of the cave in } 2002 .\end{array}$ \\
\hline 3 & $\begin{array}{l}\text { Castañar de Ibor } \\
\text { Cave }\end{array}$ & Spain & $\begin{array}{l}\text { Located in the Villuercas-Ibores-Jara Geopark, this is a karstic cave whose importance } \\
\text { and uniqueness derives from the fact that it is excavated out of Precambrian materials } \\
\text { (540 Ma) and contains some spectacular speleothems. It has high radioactivity (radon). } \\
\text { Since 2008, due to a fungal outbreak, access is limited to small groups of visitors } \\
\text { wearing protective suits with hand-held or helmet-mounted torches. }\end{array}$ \\
\hline 4 & Las Maravillas Cave & Spain & $\begin{array}{l}\text { Cave developed on limestone and marble from the Cambrian period (over } 500 \text { million } \\
\text { years old). It is located within the urban layout of Aracena (Huelva) and has been } \\
\text { declared a Property of Cultural Interest. It contains karst formations of extraordinary } \\
\text { beauty. The development of lampenflora communities has been controlled using } \\
\text { hypochlorite. }\end{array}$ \\
\hline 5 & Zuheros Cave & Spain & $\begin{array}{l}\text { Also known as the Los Murciélagos cave. It is known for its archaeological excavations, } \\
\text { and has been declared a Property of Cultural Interest and a Natural Monument. Studies } \\
\text { have recently been done on the diversity and structure of its biofilm communities. }\end{array}$ \\
\hline 6 & El Tesoro Cave & Spain & $\begin{array}{l}\text { The only cave of underwater origin known in Europe. Of major scientific, historic and } \\
\text { cultural interest: it is the site of discoveries of rock paintings and stone and ceramic } \\
\text { remains from the Neolithic era. Declared a Property of Cultural Interest. Comparative } \\
\text { studies have been done in this cave between hydrogen peroxide and sodium } \\
\text { hypochlorite for the elimination of lampenflora. Liquid nitrogen has also been used and } \\
\text { LED lighting has been installed ( } 590 \mathrm{~nm} \text { ). }\end{array}$ \\
\hline 7 & Nerja Cave & Spain & $\begin{array}{l}\text { Declared a Property of Cultural Interest, it has } 589 \text { rock paintings dating from the } \\
\text { upper Palaeolithic era. This is one of the most visited caves in Spain. Studies have been } \\
\text { done on the emission spectrum of photosynthetic organisms, identifying their pigments } \\
\text { and the least favourable range of wavelengths for their development. A new lighting } \\
\text { system has been designed on this basis. Experiments have also been done to eliminate } \\
\text { lampenflora with calcium hypochlorite. }\end{array}$ \\
\hline 8 & Las Ventanas Cave & Spain & $\begin{array}{c}\text { Declared a National Monument, camouflage methods have been used here to conceal the } \\
\text { lampenflora communities. }\end{array}$ \\
\hline 9 & Gelada Cave & Spain & $\begin{array}{c}\text { Located in the Serra Gelada nature reserve, it was corroborated in this cave that the } \\
\text { main stress factor for biofilms was the lack of light, followed by moisture deficit, lack of } \\
\text { nutrients and temperature variations. }\end{array}$ \\
\hline 10 & $\begin{array}{c}\text { Ortigosa } \\
\text { de Cameros Caves }\end{array}$ & Spain & $\begin{array}{l}\text { Comprising the La Paz and La Viña caves, they have been the site of studies aimed at } \\
\text { increasing the threshold concentration of hydrogen peroxide necessary to eliminate the } \\
\text { lampenflora communities. }\end{array}$ \\
\hline 11 & Collbató Cave & Spain & $\begin{array}{l}\text { Also called the Montserrat Caves, they served as the inspiration for the artist Antoni } \\
\text { Gaudi when he designed the Sagrada Familia basilica (Barcelona). Studies have recently } \\
\text { been done on the diversity and structure of their biofilm communities. }\end{array}$ \\
\hline 12 & Lascaux Cave & France & $\begin{array}{l}\text { Declared a UNESCO World Heritage site in } 1979 \text {, this is one of the most important } \\
\text { manifestations of Palaeolithic and cave art, and contains magnificent prehistoric } \\
\text { depictions, including almost } 1,500 \text { etchings and } 600 \text { Palaeolithic paintings. This } \\
\text { cave has suffered successive biological crises, leading to irreversible change in its } \\
\text { ecological conditions and the discontinuation of tourist activity. It was the first cave in } \\
\text { which a complex study was undertaken on the biodeterioration processes caused by } \\
\text { photosynthetic microorganisms on its interior, and specifically on the cave paintings. }\end{array}$ \\
\hline 13 & Moidons Cave & France & $\begin{array}{l}\text { Located in the Jura massif, this cave has combined tourist activity with the assessment } \\
\text { and practical application of a germicidal treatment with UV-C radiation applied to } \\
\text { different types of biofilms. }\end{array}$ \\
\hline 14 & $\begin{array}{l}\text { Crypt of the } \\
\text { Original Sin }\end{array}$ & Italy & $\begin{array}{l}\text { A series of paleo-Christian Byzantine frescoes dating from the } 9 \text { th century and located } \\
\text { in the municipality of Mater. They represent different biblical scenes, particularly } \\
\text { corresponding to the Creation. Affected by communities of phototrophic microorganisms, } \\
\text { this is an example of the poor use of biocides to treat these communities: although } \\
\text { these products eliminated the microorganisms, the colorimetric analyses also revealed } \\
\text { changes in the colour of the substrate after treatment. }\end{array}$ \\
\hline 15 & Frasassi Caves & Italy & $\begin{array}{l}\text { Network of karstic caves located in the Gola della Rossae di Frasassi Nature Reserve. } \\
\text { They constitute one of the most important speleological sites in all Italy. These caves } \\
\text { were the site of one of the earliest tests to assess the corrosive action of sodium } \\
\text { hypochlorite. }\end{array}$ \\
\hline 16 & Grotta Gigante & Italy & $\begin{array}{l}\text { Inaugurated in 1908, this is the largest show cave in the world. UV-C radiation is used } \\
\text { here to limit and control the proliferation of photosynthetic microorganisms. }\end{array}$ \\
\hline 17 & Vilenica Cave & Slovenia & $\begin{array}{l}\text { Its importance is not due to its geological or archaeological worth, but to the fact that } \\
\text { since } 1633 \text { it has been recognised as the most important show cave in the world. }\end{array}$ \\
\hline 18 & Škocjan Caves & Slovenia & $\begin{array}{l}\text { Included on the UNESCO's World Heritage list since 1986, this group of limestone caves } \\
\text { in the Kras region is one of the best places in the world to study karstic phenomena. }\end{array}$ \\
\hline 19 & Sezana Hospital & Slovenia & $\begin{array}{l}\text { Healthcare facility with caves that are used as a speleotherapy centre for the treatment } \\
\text { of patients with pulmonary ailments. It uses dispersed lighting that hinders the } \\
\text { development of lampenflora communities. }\end{array}$ \\
\hline
\end{tabular}




\begin{tabular}{|c|c|c|c|}
\hline 20 & Postojna Cave & Slovenia & $\begin{array}{l}\text { This is the largest cave in the Kras region, in addition to one of the most visited caves } \\
\text { in Europe. This was the third cave to be equipped with permanent electrical lighting, in } \\
\text { 1884. Hydrogen peroxide is used to eliminate the lampenflora communities. }\end{array}$ \\
\hline 21 & Kraushöhle & Austria & $\begin{array}{c}\text { This cave is unique in Europe due to its speleothems with a sulphuric origin. Its } \\
\text { importance also lies in the fact that it was the second cave equipped with permanent } \\
\text { electric lighting, in } 1883 \text {. }\end{array}$ \\
\hline 22 & $\begin{array}{l}\text { Moravian Karst } \\
\quad \text { Caves }\end{array}$ & $\begin{array}{l}\text { Czech } \\
\text { Republic }\end{array}$ & $\begin{array}{l}\text { The Moravian Karst is a protected nature reserve of } 92 \mathrm{~km}^{2} \text { which includes over } 1,100 \\
\text { caves, } 14 \text { of which are adapted for tourist use. Sodium hypochlorite is used to eliminate } \\
\text { biofilms. }\end{array}$ \\
\hline 23 & Katerinska Cave & $\begin{array}{c}\text { Czech } \\
\text { Republic }\end{array}$ & $\begin{array}{c}\text { Part of the Moravian Karst, it was one of the first caves in which hydrogen peroxide was } \\
\text { used to eliminate the problem of lampenflora. }\end{array}$ \\
\hline 24 & Javořičko Cave & $\begin{array}{l}\text { Czech } \\
\text { Republic }\end{array}$ & $\begin{array}{l}\text { Underground system comprising a labyrinth of galleries and chasms that remained } \\
\text { undiscovered until 1938. Dead bats were found after treatment with sodium } \\
\text { hypochlorite. }\end{array}$ \\
\hline 25 & $\begin{array}{l}\text { Aggtelek or Baradla } \\
\text { Cave }\end{array}$ & Hungary & $\begin{array}{l}\text { Included on the UNESCO's list of World Heritage sites since 1995, it is the largest } \\
\text { stalactite cave in Europe. Since they were adapted in } 1920 \text { as a tourist attraction, } \\
\text { the lampenflora communities have spread quite fast, and there are now focuses of } \\
\text { colonisation distant from the illuminated areas. }\end{array}$ \\
\hline 26 & Alistrati Cave & Greece & $\begin{array}{l}\text { In this cave, low-pressure sodium vapour lamps were not effective in preventing the } \\
\text { development of lampenflora. }\end{array}$ \\
\hline 27 & Ali-Sadr Cave & Iran & $\begin{array}{l}\text { This is the largest aquatic cave in the world, and attracts millions of visitors each year. } \\
\text { Studies have been done to increase the threshold concentration of hydrogen peroxide } \\
\text { necessary to eliminate the lampenflora communities. }\end{array}$ \\
\hline 28 & $\begin{array}{l}\text { Cango Caves (South } \\
\text { Africa) }\end{array}$ & South Africa & $\begin{array}{l}\text { These are among the most important show caves on the African continent and attract } \\
\text { numerous local and foreign visitors. They contain an extensive system of tunnels and } \\
\text { chambers with a length of over } 4 \mathrm{~km} \text {. Hydrogen peroxide combined with UV-C radiation } \\
\text { has been used to eliminate the lampenflora communities. The use of green light was also } \\
\text { suggested (around } 530 \mathrm{~nm} \text { ) to limit their growth. }\end{array}$ \\
\hline 29 & Ha Long Bay Cave & Vietnam & $\begin{array}{l}\text { Its karst formations and islands were declared a UNESCO World Heritage site in } 1994 \text {, } \\
\text { and since } 2011 \text { it has been known as one of the seven natural wonders of the world. The } \\
\text { lampenflora growing in its formations is presented to visitors as a tourist attraction. }\end{array}$ \\
\hline 30 & Jenolan Caves & Australia & $\begin{array}{l}\text { They are located in the Blue Mountain region, and were declared a World Heritage site } \\
\text { by the UNESCO in } 2000 \text {. In the 1980s, as in many caves, pressurised water was used } \\
\text { to clean speleothems covered by algae. This area was the venue for the } 7 \text { th International } \\
\text { ISCA Congress in November } 2014 \text {, where the management document entitled } \\
\text { "Recommended International Guidelines for the Development and Management of Show } \\
\text { Caves" was agreed. }\end{array}$ \\
\hline 31 & Waitomo Cave & New Zealand & $\begin{array}{l}\text { Cave colonised by bioluminescent insects, where several experiments have been done } \\
\text { to control the lampenflora communities: use of steam or hot water at low pressures, } \\
\text { instead of cold water at high pressures, calcium hypochlorite and ultraviolet lamps. }\end{array}$ \\
\hline 32 & Ruakuri Cave & New Zealand & $\begin{array}{c}\text { Near the Waitomo Caves, tests using calcium hypochlorite were also done in the late } \\
\text { 1970s to control the lampenflora communities. }\end{array}$ \\
\hline 33 & $\begin{array}{c}\text { Oregon Caves } \\
\text { National Monument }\end{array}$ & Oregon, USA & $\begin{array}{l}\text { Cave developed on marble and declared a National Monument. Exhaustive studies have } \\
\text { been carried out on the composition of the lampenflora communities, and over } 100 \\
\text { species have been identified. }\end{array}$ \\
\hline 34 & $\begin{array}{l}\text { Carlsbad Caves } \\
\text { National Park }\end{array}$ & $\begin{array}{l}\text { New Mexico, } \\
\text { USA }\end{array}$ & $\begin{array}{c}\text { Group of caves declared a UNESCO World Heritage site in 1995. This national park } \\
\text { comprises } 83 \text { independent caves that emerged around } 250 \text { million years ago and attract } \\
\text { hundreds of tourists and potholers. Exhaustive studies have been carried out } \\
\text { on the composition of the lampenflora communities, and a total of } 200 \text { species } \\
\text { have been identified. }\end{array}$ \\
\hline 35 & $\begin{array}{l}\text { Natural Bridge } \\
\text { Caverns }\end{array}$ & Texas, USA & $\begin{array}{l}\text { Declared a United States National Natural Landmark, the lampenflora in these caves is } \\
\text { considered a tourist attraction, and its managers do not contemplate its removal. }\end{array}$ \\
\hline 36 & $\begin{array}{l}\text { Mammoth Cave } \\
\text { National Park }\end{array}$ & $\begin{array}{l}\text { Kentucky, } \\
\text { USA }\end{array}$ & $\begin{array}{c}\text { Declared a national park in 1941, a UNESCO World Heritage site in } 1981 \text { and a } \\
\text { biosphere reserve in 1990. This is the longest known cave system in the world. It was } \\
\text { successfully demonstrated that the development of lampenflora could be controlled } \\
\text { through the use of LED illumination. An emission range of } 595 \mathrm{~nm} \text { (yellow) was used, } \\
\text { preventing its growth for } 11 / 2 \text { years after its installation. }\end{array}$ \\
\hline 37 & Luray Caverns & Virginia, USA & $\begin{array}{l}\text { A UNESCO World Heritage site since 1973, this is the fourth largest cave in the United } \\
\text { States and the first with permanent electrical lighting, installed in } 1881 .\end{array}$ \\
\hline 38 & Las Manos Cave & Argentina & $\begin{array}{l}\text { This is one of the few archaeological sites in the Argentinian part of Patagonia and } \\
\text { among the most beautiful and oldest artistic expressions of the South American peoples. } \\
\text { It was declared a UNESCO World Heritage site in } 1999 \text {. }\end{array}$ \\
\hline
\end{tabular}

\section{General characteristics of lampenflora}

The composition of lampenflora communities and their eco-physiological characteristics have been the subject of numerous studies. This section summarizes the main concepts in regard to these organisms.

Cyanobacteria, together with green (Chlorophyta) and golden (Chrysophyta) algae are the most common microorganisms identified in lampenflora communities (Padisàk et al., 1984; Hoffman, 1989;
Rajczy, 1989; Mulec, 2012), but their abundance varies from one cave to another. For example, Aley (2004) compares the composition of two different lampenflora communities in the Carlsbad Caverns National Park in New Mexico and the Oregon Caves National Monument, both in the United States. In the first, out of a total of 200 species, it was estimated that $70 \%$ of the community were cyanobacteria and $20 \%$ green algae; the abundance percentages were 
similar in the second, as out of a total of 100 species identified, 40\% were cyanobacteria and 35\% green algae. Golden algae were also present, but in very small percentages.

In a subsequent work, Mulec et al. (2008) identified 60 algae and cyanobacteria taxa colonising eight underground environments (six caves and two mines) in the karst region in Slovenia. Cyanobacteria were the most abundant (47\%), followed by green (30\%) and golden algae (23\%). The cyanobacteria were represented mainly by the species Aphanocapsa muscicola, Lyngbya $s p$. and Synechocystis $s p$. In regard to algae, the authors found mainly the genera and species Chlorocloster sp. and Navicula mutica golden algae- and Chlorella sp., Stichococcus bacillaris and Trentepohlia aurea - green algae.

In a more recent work, Mulec and Kosi (2009) showed that the most common communities of photosynthetic microorganisms in European caves are cyanobacteria (around $50 \%$ of the total), green and golden algae, the most common species are Aphanothece castagnei, Gloeocapsa sanguinea (cyanobacteria) and Stichococcus bacillaris (green algae). Other studies have reported the presence of Chlorella green algae genera in lampenflora communities in various caves around the world (Grobbelaar, 2000; Nugari et al., 2009; Urzi et al., 2010; Cennamo et al., 2012; Mulec, 2012).

Although this group of algae may live independently in nature, most of the microorganisms tend to form multicellular communities known as "biofilms". Nikolaev and Plakunov (2007) state that between 95\% and $99 \%$ of microorganisms in natural environments live in the form of biofilms which represent a privileged lifestyle for most microorganisms (Ragon, 2011).

Although the diversity of the lampenflora communities inside the caves is poor in comparison with those growing naturally at the entrances (Mulec, 2012), biofilms may constitute complex biocoenoses, in which cyanobacteria and algae coexist with bacteria, fungi and yeasts (Cooksey, 1992; Jones, 1995; Jurado et al., 2010). Kumar and Anand (1998) determined that the biofilms with the greatest diversity are the most resistant to unfavorable external conditions.

Chemically, biofilms are composed mainly of water ( 70-90\%), organisms with a diverse metabolism and a hydrated matrix of extracellular polymeric substances (EPS) that they themselves segregate, composed of polysaccharides, lipopolysaccharides, proteins, glycoproteins, lipids, glycolipids, fatty acids and enzymes (Flemming, 1993; Warscheid \& Braams, 2000).

This matrix confers a series of advantages that favour the survival of the community in hostile environments, increasing the resistance of its members to external agents or other organisms. Some of these benefits are: greater protection against sources of environmental stress (desiccation processes or exposure to UV rays, heavy metals and atmospheric contaminants), greater water retention and enhanced concentration and circulation of nutrients within the biofilm (Lawrence et al., 1991; Costerton et al., 1999; Watnick \& Kolter, 2000; De Philippis et al., 2001; Roldán \& HernándezMariné, 2009; Ragon, 2011). It has also been demonstrated that these single-cell microorganisms use a method of intracellular communication through chemical signals known as "quorum sensing", which allows them to act in a coordinated way as multicellular organisms (Davies et al., 1998; Sharif et al., 2008; Annous et al., 2009).

Although at first sight the microscopic community that comprises the lampenflora (cyanobacteria and algae) (Fig. 2) appears to be static, this is not the case. The species' successional process is fairly dynamic, and early colonisers tend to grow rapidly before being slowly displaced by more persistent organisms (Mulec, 2012).

Although algae and cyanobacteria are the most common photosynthetic organisms identified in caves, other elements that may also form part of the lampenflora communities include mosses, lichens, and sometimes even ferns and higher plants (Merdenisianos, 2005; Cigna, 2011a). In the early phases of colonization, cyanobacteria and eukaryotic

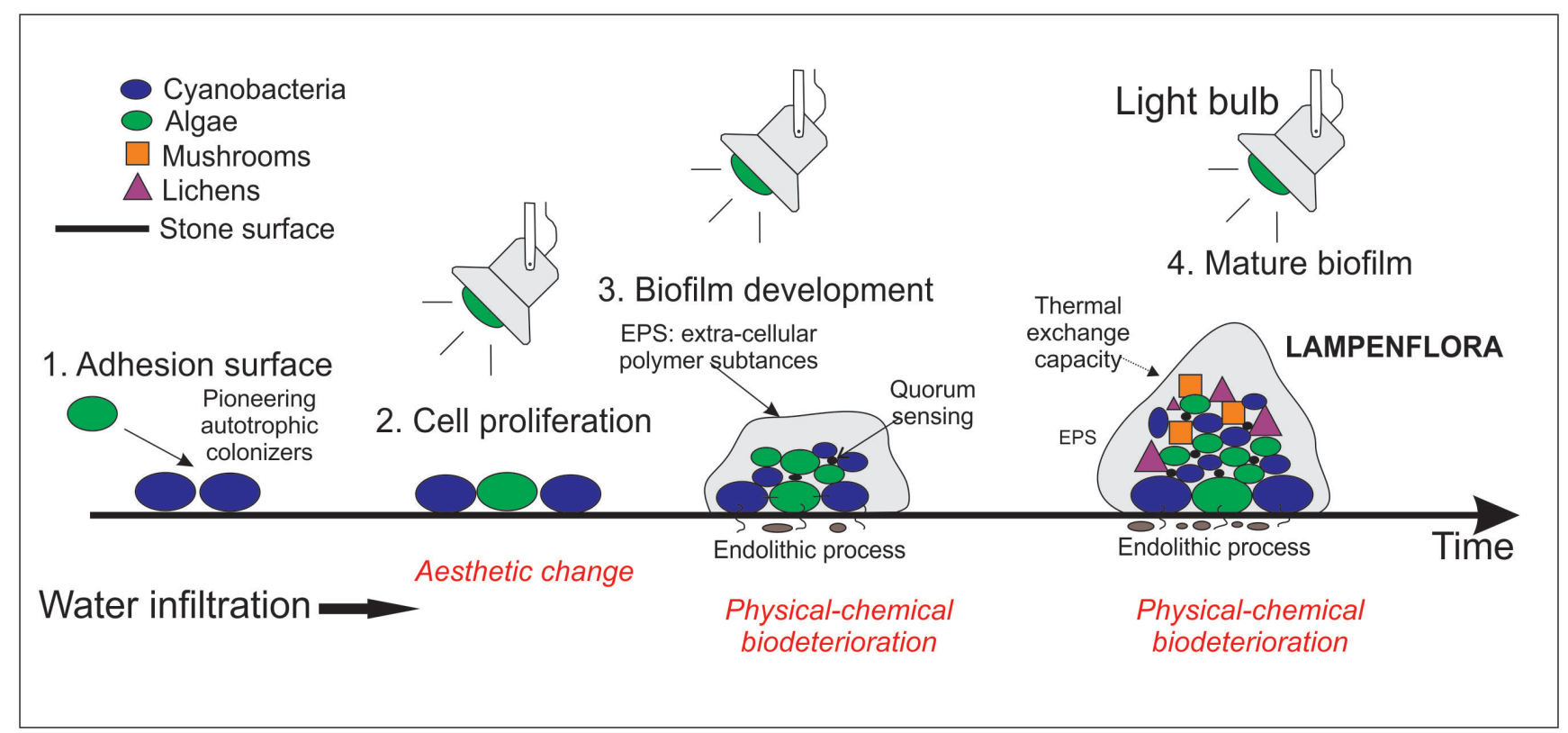

Fig. 2. Diagram of the evolution and development of biofilms in show caves (based on Di Martino, 2016). 
algae tend to play the most important role in the processes of forming the biofilm and are considered pioneering species in the ecological succession (Aleya, 1991; Gaylarde \& Gaylarde, 2000; Whitton \& Potts, 2000; Mulec et al., 2008). Subsequently, mosses and ferns develop, and the final successional phase may also include vascular plants, although almost always in the form of germinating shoots (Martincic et al., 1981).

The presence of cyanobacteria in lampenflora communities is very important from a metabolic point of view. These are the photosynthetic microorganisms that evolve most successfully in illuminated underground environments; they require no organic matter and are capable of absorbing a wide spectrum of light radiation thanks to the presence of accessory pigments (del Rosal et al., 2012). These qualities confer a significant advantage for the colonisation of new areas (Aleya et al., 1994; Herrera et al., 2004).

Thanks to their photosynthetic capacity and their nitrogen and $\mathrm{CO}_{2}$ fixing function, biofilms induce the growth of mosses and ferns in the area around them, which benefit from environments enriched in organic matter and nutrients, in turn promoting the proliferation of certain heterotrophic microorganisms (Caneva et al., 2008; Scheerer et al., 2009). This last group of microorganisms is formed by bacteria and fungi (de la Torre et al., 1991; Singh et al., 2008; Dakal \& Cameotra, 2012) and tends to be located in areas with an accumulation of organic matter such as animal excrement or detrital sediments dragged by water into the cave interior (Humpreys, 1991; Bottrell, 1996; Simon, 2012; Jurado \& Saiz-Jiménez, 2016). Other elements of an organic nature that serve as a source of nutrients are the fluff and other detritus (hairs, dry skin, dust from shoes) introduced by visitors in the case of caves adapted for tourism (Aley, 2004; Cigna, 2012; Mulec, 2012).

Of all the microorganisms present in a cave, Porca et al. (2011) consider that fungi are to a large extent the cause of greatest concern due to their high rate of production of spores and dispersion in the air. It has also been demonstrated that certain species of arthropods can not only transport fungal spores, but that many of these fungi are parasites on certain groups of insects, and ultimately kill the host and use their body to produce spores and colonise any type of organic matter present in the cave (Jurado \& SaizJiménez, 2016).

Unlike plants, fungi do not require light to grow and can be found in areas of half-light or total darkness in the caves (Aley, 1972) at some distance from the point of artificial light. However, it is only in show caves that autotrophic plants produce organic matter in a sufficient concentration to allow significant development of fungal populations (Johnson, 1979). One of the best-known cases is that of the Lascaux Cave, where the development of the alga Bracteacoccus minor as a result of the presence of artificial light (Lefèvre, 1974) and the subsequent massive colonisation by the fungus Fusarium solani marked the start of a succession of biological crises in the cave, leading to an irreversible change in its ecological conditions and the discontinuation of tourist activity (Bastian et al., 2010; Martín-Sánchez, 2012).

\section{Environmental factors conditioning the presence and development of lampenflora}

The microorganisms that form the lampenflora communities access the inside of the cave thanks to the mobility of the microorganisms themselves, or are accidentally dragged in by air currents, water flows, gravitational sedimentation through cracks and small cavities in the rock, or by the transit of cave fauna and visitors (Dobat, 1970; Vegh, 1989; Cigna, 2012; Mulec, 2012; del Rosal, 2015).

One important factor in the propagation of lampenflora is local air currents caused by the warm air generated near more powerful lamps, and particularly halogen lamps (500-1000 W) (Vegh, 1989). The growth of lampenflora has even been observed at distances of over $10 \mathrm{~m}$ when using lamps of this kind (Mulec, 2012).

Some of these factors, such as water seepage, air currents or the presence of animal and organic matter from the outside (or more generally, mass and energy flows) will in turn depend on the level of energy in the cave (Borderie et al., 2014a). Heaton (1986) introduced the concept of energy in caves, a cave that maintains high energy relations with the outside will therefore in principle be more susceptible to colonization by exogenous microorganisms, including lampenflora communities. High-energy show caves will be relatively unaffected by tourist activity, whereas caves with moderate and low energy levels are more vulnerable to anthropogenic perturbations (Grobbelaar 2000).

One of the most widespread procedures in show caves to maintaining any additional energy levels as low as possible is to limit the number of visitors based on what is known as their "carrying capacity" (Hoyos et al., 1998; Cigna, 2011b). Carrying capacity is defined as the maximum number of acceptable visitors per unit of time that can be borne by a certain ecosystem (in this case underground environments) without causing permanent modification of its most important environmental parameters. This is done by reducing the number of people or the time they spend inside the cave. Merdenisianos (2005) and Cigna (2011b) also propose the installation of double doors and air curtains at the cave entrance, with the aim of protecting the cave from changes in the microclimatic conditions, avoiding air flows into the interior and reducing the dirt deposited by the visitors. During visits to highly unique caves with high levels of protection, Jurado and Saiz-Jiménez (2016) recommend wearing protective clothing and footwear, gloves and masks to prevent inhaling the microorganisms present in the air and depositing residues from the exterior. For example, these measures have been actively implemented in the Castañar de Ibor and Altamira caves, both in Spain.

Once the access to the cave has occurred, the microorganisms adhere to the rock through several different mechanisms (Hernández-Mariné \& Roldán, 2005; Bellezza et al., 2006; Karsten et al., 2007) and 
may remain on the exterior of the substrate (epilytic) or penetrate into it (endolytic); the latter may in turn be located in pores and cavities (cryptoendolytic) or in cracks (chasmoendolytic) (Golubic, 1981).

The colonization of the different parts of the cave depends on several factors, of which the main ones are the bioreceptivity of the substrate and the environment, and the conditions of the underground medium (lighting, moisture, nutrients, and temperature).

a) The bioreceptivity of the substrate defines its potential to be colonized by different microorganisms (Guillitte, 1995; Miller et al., 2009).

Based on texture, Gillieson (1996) determined that smooth substrates generally had a lower colonization by photosynthetic microorganisms compared to rough substrates. Warscheid and Braams (2000) emphasize the porosity of the substrate, and report that materials with large pores, due to their short water retention times, promote only temporary microbial contamination, whereas small pores retain moisture for longer and offer greater protection.

Another important factor affecting the growth of lampenflora is the presence of sediment in the substrate (Martincic et al., 1981; Chang \& Chang-Schneider, 1991; Aley, 2004). Examples include the observations made by Johnson (1979) of discrete lampenflora populations in the Waitomo Caves (New Zealand). The presence of ferns, due to their very extensive root system and their erect growth pattern, is limited to areas of clay, moist mud or slightly porous limestone substrates. Mosses, which require a large amount of moistures, are also found in mud, in areas of clay and in porous limestone substrates with a constant supply of groundwater. In contrast, algae are capable of supporting much wider fluctuations in available moisture than mosses and ferns, and can develop in practically any illuminated substrate.

Finally, and in regard to the type of materials, the presence of significant amounts of carbonate and/or mineral compounds like feldspars, clays and iron minerals means these substrates are particularly susceptible to the development of microorganisms (Warscheid \& Braams, 2000). Artificial stone like bricks and mortar (which can be found inside caves that have been adapted for visitors) are also highly susceptible to microbial attack.

b) Environmental conditions. The light input, together with the availability of adequate levels of moisture, temperature and nutrients, are the most important environmental factors conditioning the presence and distribution of photosynthetic microorganisms in underground environments (Cigna, 2011a). Table 2 summarizes the environmental factors that condition the presence of lampenflora described in the preceding paragraphs.

Table 2. Environmental factors that influenced the presence of lampenflora.

\begin{tabular}{|c|c|c|c|}
\hline \multicolumn{2}{|c|}{ Factor } & \multicolumn{2}{|r|}{ Description } \\
\hline \multicolumn{2}{|c|}{ Bioreceptivity of the substrate } & \multicolumn{2}{|r|}{$\begin{array}{l}\text { Substrates with a rough texture and small pores. } \\
\text { Presence of sediments. } \\
\text { carbonate compounds, minerals susceptible to meteorological elements } \\
\text { and/or artificial stone. }\end{array}$} \\
\hline \multirow{6}{*}{$\begin{array}{l}\text { Environmental } \\
\text { conditions of the } \\
\text { underground } \\
\text { environment }\end{array}$} & \multirow[b]{2}{*}{ Lighting } & Wavelength & $\begin{array}{c}\text { The process of photosynthesis is enhanced at wavelengths in } \\
\text { the following intervals: } 430-490 \mathrm{~nm} \text { (blue light) and 640-690 nm } \\
\text { (red light). }\end{array}$ \\
\hline & & $\begin{array}{c}\text { Duration and degree of } \\
\text { intensity }\end{array}$ & $\begin{array}{l}\text { The thickness and diversity of the biofilms decreases when the } \\
\text { intensity of light is less than } 10 \text { to } 50 \text { lux in algae, } 50 \text { to } 180 \text { lux in } \\
\text { mosses and } 250 \text { lux in ferns. } \\
\text { Lampenflora communities can survive with much lower levels of } \\
\text { lighting than described previously, and even in total darkness for long } \\
\text { periods of time. }\end{array}$ \\
\hline & Humidity & \multicolumn{2}{|c|}{$\begin{array}{l}\text { The development of lampenflora is generally limited to humid environments and wet surfaces. } \\
\text { Duration of dry periods and number of humid periods. } \\
\text { Algae are capable of withstanding much greater fluctuations in the available moisture than } \\
\text { mosses and ferns, and some species may even recover their metabolic activity after prolonged } \\
\text { periods of desiccation. }\end{array}$} \\
\hline & \multirow[b]{2}{*}{ Nutrients } & \multirow{2}{*}{\multicolumn{2}{|c|}{$\begin{array}{l}\text { Obtained primarily from groundwater seeping into the cave interior. } \\
\text { Secondary sources, excrement of the animals inhabiting the cave, detrital and clayey } \\
\text { sediments dragged by water into the interior or residues introduced by visitors during } \\
\text { tourist visits (fluff, dust, hair). } \\
\text { The high levels of } \mathrm{CO}_{2} \text {, generated by visitors contribute to the increase in photosynthetic capacity. } \\
\text { Within the actual lampenflora population, there is also a cycle of nutrient utilisation, release } \\
\text { and re-utilisation by autotrophic and heterotrophic organisms. }\end{array}$}} \\
\hline & & & \\
\hline & Temperature & \multicolumn{2}{|c|}{$\begin{array}{l}\text { The microorganisms are arranged according to temperature: extremely powerful illumination } \\
\text { restricts the growth of lampenflora in the area around the artificial lighting point as a result } \\
\text { of excess heat. } \\
\text { However, lampenflora communities may continue growing in areas further away from the lamps. } \\
\text { In comparison with the exterior, the temperatures in the underground environment } \\
\text { are more uniform. }\end{array}$} \\
\hline
\end{tabular}




\section{Lighting}

Three aspects of the lighting must be considered: intensity, duration, and wavelength, as the three influence the type of development of photosynthetic biofilms.

Chlorophyll (types A and B) has two absorption peaks in the wavelength intervals of 430-490 nm (blue light) and 640-690 nm (red light), and these wavelengths are more of a hazard for the proliferation of lampenflora (Bickford \& Dunn, 1972; Caumartin, 1994; Olson, 2006; Cigna, 2011a). That is, if the lighting system used in a show cave contains these emission ranges, the process of photosynthesis will be enhanced.

Cyanobacteria, in addition to chlorophyll, possess phycobilins (phycoeritrin, phycocyanin and allophycocianin), accessory pigments that expand the absorption spectrum of the primary pigments and act as a system of protection against high light radiation (del Rosal, 2015).

In studies on the diversity and structure of the biofilms in several Spanish caves (Zuheros Cave, Nerja Cave and Collbató Cave), Roldán and HernándezMariné (2009) observed that the thickness and diversity of the biofilms decreases if the intensity of the light also decreases. In fact, the availability of photosynthetic radiation was the parameter that determined whether the microorganisms forming a biofilm were predominantly photosynthetic (algae and cyanobacteria) or heterotrophic (fungi and bacteria). Thus, areas with poor illumination were dominated by heterotrophic communities, whereas others with strong illumination were occupied mainly by photosynthetic microorganisms. In any case, the organisms present in the least illuminated areas required a supply of organic matter generated by the organisms growing in the most illuminated areas.

The light intensity measurements taken by Johnson (1979) in New Zealand caves suggest that the minimal levels of light required for the continuous growth of the various organisms that comprise the lampenflora are the following: in algae, 10 to 50 lux; in mosses, 50 to 180 lux; and in ferns, 250 lux. Cigna (2011a) simplifies these intensity levels, and states that $85 \%$ of the lampenflora develop with an approximate minimum value of 40 lux.

Detailed studies carried out on stone surface, mural paintings in rocky indoor environments and subterranean archeological sites (Albertano et al., 2000; Hoffmann, 2002; Albertano \& Bruno, 2003; Urzi et al., 2010; Albertano, 2012) also show light as the limiting factor for the growth of these phototrophic biofilms and the only parameter that can be controlled in situ. In this case, it has also been proven that the presence of artificial light with very low intensity provides a suitable environment for the development of phototrophic microorganisms (Albertano, 2012; Bruno \& Valle, 2017). Monochromatic lights, with limited wavelength emission, have been successfully tested under laboratory conditions and inside a Roman hypogean site (Albertano \& Bruno, 2003).

However, other studies suggest that established populations of lampenflora may survive for long periods of time with much lower levels of light than those mentioned previously, revealing their capacity to survive in low lighting conditions. Some algae and cyanobacteria can survive and reproduce even at light intensities considerably below what is known as the "photosynthetic compensation point" (intensity of light at which the amount of $\mathrm{CO}_{2}$ fixed in sugars during photosynthesis is the same as the $\mathrm{CO}_{2}$ released during respiration) (Martincic et al., 1981; Mulec, 2005).

Some species of algae (such as Chlorella sp.) are capable of switching from an autotrophic to a mixotrophic and finally to a heterotrophic lifestyle, deploying their reserves according to changes in lighting conditions (Kermode, 1975; Roldán \& Hernández-Mariné, 2009). Other organisms such as mosses may display etiolation, a physiological adaptation to low levels of light which involves exposing a greater surface area to capture the few photons available in periods of scarce light (Mulec, 2012).

In addition to withstanding long periods with very low levels of light, lampenflora populations can even survive in total darkness (Claus, 1962, 1964; Hajdu, 1966; Kol, 1967 in Aley, 2004). In the course of an experiment (Johnson, 1979) on the development of lampenflora under different light colors, one lamp failed after the growth of a lampenflora population. The lamp was not repaired for five months and after this period of essentially zero lighting, the associated lampenflora appeared to have suffered very little or no deterioration. In contrast, when the intensity of light is too high, some epilithic algae may switch to the endolithic phase to protect themselves from excess damage from light (Asencio \& Aboal, 2001).

\section{Moisture}

The development of lampenflora is generally limited to moister or wetter surfaces, usually located in soft porous areas with a presence of water, which accelerates their growth (Martincic et al., 1981; Aley, 2004). However, for the development of biofilms in general, the duration of the dry periods and the number of humid periods appears to be more important (Gladis-Schmacka et al., 2014) than the total amount of water available (Büdel et al., 2009).

Some organisms have developed survival strategies during periods of prolonged drought, which include using the water retained in the substrate, forming protective compounds such as saccharose or trehalose (Potts, 1999, 2001; De Philippis et al., 2001), and the advantage gained by biofilms of growing in a thin layer directly on the substrate, thus being able to optimize all the available moisture (Johnson, 1979).

Algae are capable of withstanding much greater fluctuations in available moisture than mosses and ferns (Johnson, 1979). Grobbelaar (2000) observed that some species can recover their metabolic activity after long periods of desiccation. Specifically, some genera of cyanobacteria such as Chroococcidiopsis $s p$. and Nostoc $s p$. may become desiccated without dying (Alpert, 2006) and rapidly recover in favorable conditions, withstanding wide fluctuations in 
moisture and surviving in the most extreme habitats for long periods of time (Potts, 2001; Wierzchos et al., 2006; Ramirez et al., 2011).

\section{Nutrients}

One of the characteristics of natural cave environments is their low nutrient content (Simon et al., 2007). The groundwater that seeps into the ground is the only source of almost all the nutrients necessary for the autotrophic growth of these communities. As it travels across the floor and the rock that forms the cave, the water picks up soluble inorganic nutrients that are introduced into the cave and absorbed by the lampenflora (Johnson, 1979).

As indicated above, due to their photosynthetic and nitrogen and $\mathrm{CO}_{2}$ fixing capacity, biofilms induce the growth of bacteria, fungi, mosses and ferns in their surroundings, which benefit from an environment enriched in organic matter and nutrients. Hence within the actual lampenflora population, there is a cycle of nutrient utilization, release and reutilization by the autotrophic and heterotrophic organisms (Johnson, 1979).

Other sources of nutrients already mentioned are, for example, the excrements of animals who inhabit in the cave, detrital and clay-like sediments dragged by water into the interior, and the residues introduced by visitors.

\section{Temperature}

The rise in temperature is another factor with a significant influence on the growth of algae. PulidoBosch et al. (1997) used an incandescent lamp and estimated that at a distance of $50 \mathrm{~cm}$ from the light source the temperature was $8^{\circ} \mathrm{C}$ higher than in the surroundings, whereas Cigna (2011a) claims that at a distance of a few dozen centimeters this type of lamp produces a temperature increase in the order of $10^{\circ} \mathrm{C}$ and a decrease in relative humidity of $70-80 \%$.

These conditions cause the cyanobacteria to adopt a mosaic or belt arrangement according to the environmental conditions (Roldán et al., 2004), in this case generating a central vegetation-free patch in the area around the artificial light point, as a result of the excessive heat and of the sharp decrease in moisture (Johnson, 1979; Mulec \& Kosi, 2009; Esteban, 2014).

Mulec (2012) offers an interesting example of this issue: in the Aggtelek Caves (Hungary) green patches appeared after the snow melt in spring, but when the water evaporated the green covering nearest the lamps disappeared. The intense illumination had dried the surface and restricted the growth of the lampenflora, but in the area furthest from the lamps, the flora continued growing.

At a low flow-density of photosynthetic photons, a small increase in temperature can lead to a considerable increase in the production of biomass. For example, the green alga Chlorella $s p$., frequently identified in lampenflora communities, multiplied its biomass by 30 when the temperature rose from 9 to $11^{\circ} \mathrm{C}$ (Mulec, 2012). In comparison with the cave entrance the areas around the lamps offered more stable conditions without any extreme environmental oscillations like melting-freezing processes.

Finally, the following are conditions that may exist in caves that that could promote lampenflora colinisation (Grobbelaar, 2000; Merdenisianos, 2005):

1) They are supplied with relatively constant illumination from an artificial light source.

2) Generally, the environment in caves maintains a humidity of around 100\%.

3) The water that seeps through the floor and the geological formations often contain high concentrations of nutrients.

4) The temperatures in the underground environment are more uniform than on the exterior.

5) The high levels of $\mathrm{CO}_{2}$ generated by visitors in the underground atmosphere contribute to increasing the photosynthetic capacity and as a result, to the more rapid growth of the lampenflora.

6) Fungi and other microorganisms are easily disseminated in the cave interior thanks to air currents and transport by cave fauna and visitors.

\section{Problems generated by lampenflora}

The colonisation and growth of biofilms normally involves a change in the properties of the substrate where they develop (Korber et al., 1994; Golubic \& Schneider, 2003; Prakash et al., 2003). When an undesirable change occurs, this is known as "biodeterioration" (Hueck, 1965, 1968; Kumar \& Kumar, 1999).

Numerous works have highlighted the relationship between the processes of deterioration of stone monuments in the presence of microorganisms such as bacteria, fungi, algae, mosses and lichens (OrtegaCalvo et al., 1991; Saiz-Jiménez, 1994; Warscheid \& Braams, 2000; Papida et al., 2000; Crispim \& Gaylarde, 2005; Caneva et al., 2008; Di Martino, 2016). Wakefield and Jones (1998) estimated that between $20 \%$ and $30 \%$ of the deterioration in rocks is a result of biological activity.

In underground environments, the proliferation of photosynthetic microorganisms can be considered a significant threat to the conservation of the natural and cultural heritage (Ciferri, 1999; Bastian \& Alabouvette, 2009; Albertano, 2012).

The Lascaux Cave was the first in which a complex study was conducted on the processes of biodeterioration caused by photosynthetic microorganisms on its interior, specifically on its cave paintings (Lefèvre et al., 1974). Since then, this type of deterioration has been researched by several authors, both in caves and in other underground environments or hypogeous monuments.

Nugari et al. (2009) observed in the Crypt of the Original Sin (Matera, Italy) that the communities of phototrophic microorganisms not only formed a greenish layer on the surface of the Byzantine paintings (dating from the ninth century), but that they also colonized the interior of the rock substrate to a depth of several millimeters. Del Rosal (2015) gives as an example the case of several Spanish caves in which the "uncontrolled" development of microorganisms posed a serious problem that has sometimes led to the 
closing of the cave. In the Tito Bustillo Cave, numerous speleothems were found to be abundantly colonized by photosynthetic microorganisms, including the cyanobacteria Scytonema julianum (Saiz-Jiménez, 1999). The Castañar de Ibor Cave had to be closed to the public in 2008 due to a fungal outbreak caused by a visitor's vomit which led to the development of Mucor circinelloides and Fusarium solani (Jurado et al., 2010). Finally, the growth of photosynthetic microorganisms due to intense artificial lighting caused the closure of the Altamira Cave in 2002 (SaizJiménez et al., 2011).

To understand the different processes of biodeterioration in caves, Caneva et al. (2008) indicate that it is important to know whether the microorganisms use the material as a source of nutrients, as occurs with heterotrophic organisms (bacteria and fungi), or merely serves as a physical substratum for their development, as in the case of autotrophic organisms (cyanobacteria and algae). Whether for the purposes of nutrition or residence, microbial colonization significantly alters the physical and chemical properties of the mineral substrate, improving its bioreceptivity and allowing the development of different types of patina which range from thin films through to thick crusts (Warscheid \& Braams, 2000). The negative effects of lampenflora therefore not only include changes in the aesthetic appearance of the caves (colouration), but these communities also cause a physical (disintegration) and chemical (dissolution) deterioration of the substratum.

In first place, the presence of lampenflora causes an aesthetic change to the substrate surface, producing a dirty greenish appearance (mainly due to the presence of chlorophyll-derived pigments), with the subsequent decline in aesthetic value of the colonized substratum (Warscheid \& Braams, 2000; Caneva et al., 2008; De Muynck et al., 2009; Scheerer et al., 2009; Cutler et al., 2013). When the algae are grouped in biofilms, the presence of the extracellular matrix (EPS) acts as a viscous adhesive, providing sufficient resistance to adhere to the colonized surfaces (Karsten et al., 2007) and in turn promoting the retention of dust particles and certain atmospheric aerosols, which contribute to the change in color (Steiger et al., 1993; Warscheid \& Braams, 2000; Mulec, 2012).

Physical biodeterioration includes all the mechanisms that produce structural changes, loss of cohesion, rupture or disintegration of the substrate through mechanical pressure due to the growth of microorganisms (Caneva et al., 2008, Warscheid $\&$ Braams, 2000). One example of this process is the penetration of the filaments of some endolithic species (certain algae and filamentous cyanobacteria) in the cracks in the substrate. The absorption of water and the cellular growth of these organisms exert pressure on the structure, which leads to the detachment and peeling of the surface layers of the substrate (Krumbein, 1988; Danin \& Caneva, 1990; Bolivar \& Sánchez-Castillo, 1997; Asencio \& Aboal, 2001; Peraza-Zurita et al., 2005; Sarró et al., 2006). The extracellular matrix (EPS) may also play a role in biodeterioration, generating an additional physical chemical stress due to the processes of hydration or dessication (Dornieden et al., 2000; Warscheid \& Braams, 2000; Perry et al., 2004; Borderie et al., 2014a).

Chemical biodeterioration is mainly due to the metabolic activity of microorganisms, also known as "biocorrosion"; this is a process whereby the microorganisms excrete a series of organic acids (oxalic, citric, gluconic, fumaric, malic, and formic acid, among others) which cause the dissolution of materials and calcium carbonate formations in monuments and caves (Johnson, 1979; Warscheid \& Braams, 2000; Herrera et al., 2004; Aley, 2004; Caneva et al., 2008; Scheerer et al., 2009). Electron transfer, the absorption of protons and cations from the substrate due to the formation of chelating complexes and phototrophic processes (including carbon dioxide transfer, oxygen production, and alkaline reactions with variations in $\mathrm{pH}$ ), also contribute to the biodeterioration of the substrates and the precipitation of mineral mixtures (Albertano, 1993; Albertano et al., 2000; Warscheid \& Braams, 2000; Hoffmann, 2002). All these biological activities lead to the alteration of the minerals and cause changes in the rock structure, involving greater porosity and permeability to water (Warscheid \& Braams, 2000) and a weakening of its physical support function.

A particularly serious problem arises when the lampenflora, either living or dead, gradually becomes encrusted in the calcium carbonate substrate due to abiotic or biotic processes of precipitation and carbonate deposit. This amorphous mixture of dead phototrophs and carbonates irreversibly destroys the speleothems and other objects of cultural value (Mulec, 2012).

The presence of lampenflora also poses a problem for the fauna inhabiting the caves (Mulec \& Glažar, 2011), as biofilms add a substantial amount of nutrients to the cave environment, available both to animals that are adapted to the underground environment and to other occasional inhabitants. It has been suggested that in this new environment, newcomers may become more competitive in this ecological niche and displace other autochthonous populations, affecting both their diversity and their abundance. However, these kind of effects have not been studied in a systematic and quantitative fashion yet and many conclusions may be merely speculative, particularly regarding higher order organisms. There are even works such as that by Meyer et al. (2017) where $T$. celsus is used as a biological model, that show no evidence of lampenflora-induced alteration of the subterranean food chain after the application of sodium hypochlorite.

Biodeterioration can be seen as a complex ecological process driven by numerous interactions between microorganisms, the substrate, and environmental factors described above (light, humidity and temperature, among others) (Nuhoglu, 2006; Dakal \& Cameotra, 2012; Miller et al., 2012). Table 3 summarizes the problems generated by lampenflora in show caves. 
Table 3. Problems generated by lampenflora in show caves.

\begin{tabular}{|c|c|c|c|}
\hline \multicolumn{2}{|c|}{ Type } & Causes & Consequences \\
\hline \multicolumn{2}{|c|}{ Aesthetic changes } & $\begin{array}{l}\text { Presence of pigments derived from chloroform } \\
\text { in the biofilms. } \\
\text { The extracellular matrix (EPS) acts as a viscous } \\
\text { adhesive, favouring the retention of dust } \\
\text { particles and certain atmospheric aerosols. }\end{array}$ & $\begin{array}{c}\text { Change of colour: dirty greenish colour. } \\
\text { Loss of aesthetic value in the colonised } \\
\text { substratum. }\end{array}$ \\
\hline \multirow[b]{2}{*}{ Biodeterioration } & Physical & $\begin{array}{l}\text { Mechanical pressure due to the cellular growth } \\
\text { of microorganisms. } \\
\text { Penetration of some endolithic species within } \\
\text { the cracks in the substrate. } \\
\text { Processes of hydration and/or desiccation of the } \\
\text { extracellular matrix (EPS). }\end{array}$ & $\begin{array}{l}\text { Peeling and exfoliation of the surface layers } \\
\text { of the substrate. } \\
\text { Structural changes: loss of cohesion, rupture or } \\
\text { disintegration of the colonised substratum. } \\
\text { Greater porosity and permeability to water. }\end{array}$ \\
\hline & Chemical & $\begin{array}{l}\text { Metabolic activity of the microorganisms } \\
\text { and excretion of organic acids (oxalic, citric, } \\
\text { gluconic, fumaric, malic and formic acids, } \\
\text { among others). } \\
\text { Transfer of electrons and absorption of protons } \\
\text { and cations in the substrate due to the } \\
\text { formation of chelating complexes. } \\
\text { Phototrophic processes including carbon } \\
\text { dioxide transfer, oxygen production and alkaline } \\
\text { reactions with variations in pH. }\end{array}$ & $\begin{array}{l}\text { Dissolution of the materials. } \\
\text { Alteration and precipitation of mineral mixtures. }\end{array}$ \\
\hline
\end{tabular}

\section{METHODS FOR CONTROLLING LAMPENFLORA}

Historically the control of lampenflora communities involves two actions: the elimination of existing biofilms, and the prevention or delay of their development (Johnson, 1979; Hebelka, 2014). This control has led to the publication of an extensive bibliography on the work carried out in some of the world's most important show caves, where this problem has been studied and treated for decades. Mulec and Kosi (2009) highlight the contradiction of eliminating the phototrophic communities without removing or modifying the lighting in the caves, and thus without restricting their use by tourists, which would be unacceptable to their managers. These authors also say that in spite of the availability of several methods to control lampenflora, no definitive technique for preventing and avoiding their growth has yet been found.

The control methods tested can be classified into three main categories: physical, chemical and environmental. The following sections present and describe the main features of these methods.

\section{Physical methods}

Brushing and washing with pressurized water

Mechanical elimination using brushes and pressurized water are two mechanical techniques traditionally used to address the problem oflampenflora in show caves. The use of pressurized water injectors is very widespread among the managers of Australian show caves (Newbould, 1974; Anon, 1976) and, as indicated by the studies of Bonwick et al. (1986) in the Jenolan Caves (Australia), pressurized water is considered safe for cleaning speleothems covered by algae (cited in Werker \& Hildreth-Werker, 2004).

Both brushing and washing with pressurized water have been found to be very efficient on hard surfaces, and offer instant results without generating any toxic products (Ramírez-Trillo \& González-Ríos, 2014). However, the use of these two techniques has currently been curtailed for the following reasons:

- Their long-term effectiveness is very low (Hebelka, 2014).

- Contrary to the declarations of Bonwick et al. (1986), it has been demonstrated that the repeated use of these techniques may cause damage to soft or earthy surfaces and alter the fragile crystalline structures of the speleothems (Ash et al., 1975; Spate \& Moses, 1994; Merdenisianos, 2005; Mulec \& Kosi, 2009; Mulec, 2012). The presence of calcified algae in many speleothems means that this type of mechanical method cannot be applied effectively without damaging the external calcareous structure (Esteban, 2014).

- The use of these methods causes the biological contamination to disperse more easily around the cave towards other unaffected surrounding areas (Rajczy, 1989; Hazslinszky, 2002; Hebelka, 2014).

The only exception in which highly pressurized water could be used is to eliminate dead plant matter and clean the surface of the cave after treatment with chemical products (Johnson, 1979). Werker and Hildreth-Werker (2004) recommend that if this method is applied, water from the interior of the cave or from the aquifer where it is located should be used, as the surface water may be chemically aggressive and damage the speleothems. Ramirez-Trillo and González-Ríos (2014) recommend a pressure of no more than two bars, and suggest the use of a liquid aspirator to collect remnants from the treatment.

\section{Camouflage}

Camouflage is designed to conceal the lampenflora communities and avoid their visual impact, but does not include any measures to prevent their subsequent development or eliminate them. This type of method has been applied on very few occasions. In the Las Ventanas Cave (Spain), colonies established in earthy 
or sandy areas were disguised by mixing the surface with deeper materials. The more consistent substrates were rubbed with clay and earth and finally, the loose stones that were affected were turned over (RamírezTrillo \& González-Ríos, 2014).

\section{Radiofrequencies}

The test carried out by Cennamo et al. (2013) based on the use of nonthermal effects of radiofrequencies seems to demonstrate that this kind of radiation produces visual disappearance of biofilms after a month of treatment. Treated stones, when transferred back to their original sites, did not show any microorganism re-growing after 6 months. It would be quite interesting to modify this technique only applicable in the laboratory for now, to test its efficiency in the show caves.

\section{Chemical methods}

\section{Sodium hypochlorite}

Sodium hypochlorite, $\mathrm{NaClO}$, whose solution in water is known as bleach, is a strongly oxidative chemical compound that is often used as a disinfectant to produce drinking water and as a bleach in the textile industry or for domestic use (Hebelka, 2014). Commercial hypochlorite solutions (bleach) show variable concentrations depending on the manufacturer and the end use of the product. Household bleach sold for clothes laundering is a $3-8 \%$ sodium hypochlorite solution (OxChem, 2014). A $12 \%$ solution is widely used for water chlorination, and a $15 \%$ solution is more commonly used for disinfection of wastewater in treatment plants. The strength of these solutions decreases gradually with storage time, thus, actual concentration may differ from that specified in the container.

Since the late 1970s it has also been applied at a concentration of nearly $5 \%$ to restrict and eliminate lampenflora communities in show caves (Johnson, 1979; Aley et al., 1984; Zelinka et al., 2002; Aley, 2004; Cigna, 2011a; Mulec, 2012). Hebelka (2014) provides another example of the efficacy of this type of treatment based on the results obtained in the Moravian Karst (Czech Republic). An average cleaning efficiency of $80 \%$ was achieved by applying a $4 \%$ solution of sodium hypochlorite. The concentration of hypochlorite may be increased up to $8 \%$ in areas with a thick growth of biofilms however the efficacy of this method is highly variable, as it depends on numerous factors: a) Concentration of hypochlorite (chlorine) in the solution used. b) Density and type of plant matter to be eliminated. c) Type of substrate on which the lampenflora are growing. d) Amount of water present in the treated area. e) Age of the chemical agent used.

On the other hand, the most recent studies prove that usual $\mathrm{NaClO}$ concentrations to treat lampenflora are unnecessarily high (Meyer et al., 2017): "the success of $\mathrm{NaClO}$ is even more notable since the concentrations where an order of magnitude $(0.5 \%)$ lower than the recommended guidance". They suggest that it would be environmentally safe to use hypochlorite below $0.5 \%$, although they do not provide experimental evidence.
Hypochlorite breaks down fast (between 5 minutes and 12 hours) in contact with organic substances, producing rapid oxidation of the substrate. When applied on lampenflora it leads to its degradation and whitening (Johnson, 1979; Hebelka, 2014). Treatment with sodium hypochlorite is approved and widespread in numerous caves, as it does not cause any significant damage to the formations and has a satisfactory final result. Nevertheless, some species of filamentous cyanobacteria trapped within the microcavities of the substrate, mainly Scytonema julianum and Leptolyngbya $s p$, are capable of resisting the treatment with hypochlorite (IliopoulouGeorgoudaki et al., 1993).

One advantage of $\mathrm{NaClO}$ solutions over $\mathrm{H}_{2} \mathrm{O}_{2}$ solutions is that the former are much less corrosive. In tests to assess the corrosive action of sodium hypochlorite on some broken formations in the Frasassi caves (Italy), Bertolani et al. (1991) found that with ten minutes of treatment and after 17 hours, only $41 \mathrm{mg} / \mathrm{m}^{2}$ of rock was dissolved.

The use of $\mathrm{NaClO}$ may represent a negative burden for the environment in the cave, as the products resulting from its oxidation are carbon dioxide, water and chloride ions, and it may also cause the release of chlorine gas (Faimon et al., 2003; Mulec \& Kosi, 2009), a highly toxic compound when inhaled or in contact with the skin. It must be applied by personnel wearing adequate protective equipment (overalls with a hood, boots and rubber gloves, protective goggles and a respirator) and depending on the size of the area to be treated, using a manual spray device or a backpack sprayer (Hebelka 2014).

In 1981 a group of speleologists found dead bats in the Javořičko Cave (Czech Republic) after cleaning operations with sodium hypochlorite solutions. The disappearance of some species of insects in Slovak caves may also be related to the biocidal effect of hypochlorite on underground fauna (examples cited in Faimon et al., 2003), the chlorine released contaminates the atmosphere, generates an unpleasant odor, and even acidifies the karstic waters, leading to the possible dissolution and erosion of calcium carbonate formations.

Iliopoulou-Georgoudaki et al. (1993) indicate that the use of sodium hypochlorite may also cause a reddish colouring in the carbonate substrates due to the oxidization of $\mathrm{Fe}^{2+}$ into $\mathrm{Fe}^{3+}$, which precipitates as amorphous iron hydroxide $\mathrm{Fe}(\mathrm{OH})_{3}$ (cited in Mulec $\&$ Kosi, 2009). In these cases, careful rinsing of the substrate with deionized water must be conducted after treatment in order to avoid undesirable effects and further damages.

Finally, other substances may be formed while spraying sodium hypochlorite, originated by the interaction with the biota. These subproducts are usually known as AOX (adsorbable organic halides) (Drewes \& Jekel, 1998). For example, toxic chloramines are released when hypochlorite reacts with ammonia and nitrogenated compounds, (Greenwood \& Aernshaw, 1984; Delalu et al., 2001) and may even form carcinogenic trihalomethanes (Faimon et al., 2003). All these products can significantly foul up 
a cave environment and negatively influence native cave biota (Faimon et al., 2003).

However, these consequences can be minimised if the show caves where the treatment with $\mathrm{NaClO}$ is applied are adequately ventilated (Johnson, 1979; Cigna, 2011a), and the same recommendations are observed (Hebelka, 2014):

\section{Calcium hypochlorite}

Calcium hypochlorite, $\mathrm{Ca}(\mathrm{ClO})_{2}$, like sodium hypochlorite, is a fast-degrading compound with a strong oxidizing effect used as a disinfectant and bleach, and which has also been used to control lampenflora communities (Hebelka, 2014).

In large-scale tests carried out in the Ruakuri and Waitomo caves, Johnson (1979) indicates that the concentration of calcium hypochlorite necessary for the effective control of lampenflora depends on the composition and density of the biofilms to be treated. In places where there is a fine covering of algae, a $2 \%$ solution in water was sufficient to clean the surface, whereas if the lampenflora was constituted by a dense community of mosses and algae it was necessary to apply a $4 \%$ solution.

In terms of its effectiveness in cleaning speleothems, an exhaustive test was done in the Nerja Cave (Garrido et al., 2007). On this occasion, a solution of water saturated in calcite and calcium hypochlorite $(2 \%)$ was used. The treated areas revealed an intense fungal colonization of the cleaned surface a few days after the treatment was applied. A further application of hypochlorite was made to eliminate the fungi and the remnants of dead microorganisms remaining on the substrate, which constituted a source of nutrition for these fungi. One year after the cleaning process, the recolonization of the substrate by photosynthetic microorganisms was defined as "practically unnoticeable". However, in 2011, five years later, the areas that had been cleaned once again showed colonization by photosynthetic microorganisms.

The environmental effects of treatment with $\mathrm{Ca}(\mathrm{ClO})_{2}$ are similar to the use of $\mathrm{NaClO}$, as both compounds are based on the action of chlorine (Faimon et al., 2003; Mulec \& Kosi, 2009). However, Johnson (1979) downplays the problem of the strong odor and claims that 36 hours after treatment with four liters of calcium hypochlorite at $4 \%$ in an unventilated area of the Waitomo caves, the smell of chlorine was undetectable. Aley (2004) do not recommend its use, as calcium hypochlorite solutions leave a calcium residue that is difficult to eliminate. Mulec and Kosi (2009), Iliopoulou-Georgoudaki et al. (1993) noted that, as occurs with sodium hypochlorite, these substances are responsible for the development of a reddish coloring in carbonate substrates due to the oxidation of $\mathrm{Fe}^{2+}$ into $\mathrm{Fe}^{3+}$ that precipitates as an amorphous iron hydroxide, $\mathrm{Fe}(\mathrm{OH})_{3}$.

\section{Hydrogen peroxide}

In order to avoid the environmental drawbacks of the use of hypochlorite in the treatment of lampenflora, in the early 21 st century several authors (Grobbelaar, 2000; Kubesová et al., 2000; Faimon et al., 2001,
2003) have proposed the use of hydrogen peroxide $\mathrm{H}_{2} \mathrm{O}_{2}$ as an alternative agent. Hydrogen peroxide is a colorless liquid, miscible with water in all proportions, and whose use does not leave residues that may negatively affect the environment, as it dissociates in oxygen and water (Grobbelaar, 2000), and does not release any toxic substance after its degradation.

This substance has long been used as an antiseptic and antibacterial agent in the healthcare sector and as a bleach and disinfectant in numerous industries. In its undiluted form it is a highly corrosive and aggressive oxygen that is difficult to handle. For this reason, Mulec and Kosi (2009) noted that it is crucial to estimate a sufficient concentration to destroy the lampenflora without deteriorating the speleothems. Based on the tests carried out in the Katerinska Cave (Czech Republic), Faimon et al. (2003) considered that the threshold concentration of $15 \%$, applied three times during a period of between two to three weeks, is sufficient to destroy small developments of cyanobacteria, algae and mosses. However, this experiment is difficult to interpret. Authors started with a $5 \%$ peroxide concentration and gradually increased it up to $15 \%$ always applying the product onto the same area. This last concentration was considered effective as they observed lampenflora disappearing. Nevertheless, they did not take into account the cumulative effect of successive applications and the results just show the concentration but not the total amount of product applied per unit area or time.

Several authors (Faimon et al., 2003; Esteban, 2014; Mulec, 2014) highlight the difficulty of eliminating highly developed growth or lampenflora communities encrusted in a calcium carbonate substrate with a single application. There are two ways of increasing the effectiveness of treatment with $\mathrm{H}_{2} \mathrm{O}_{2}$ and reducing the number of applications:

1) Accumulated mosses and ferns must be removed before applying the peroxide, thus avoiding the need to repeat the treatment during humid periods after heavy rains (Mulec \& Glažar, 2011).

2) The threshold concentration of $\mathrm{H}_{2} \mathrm{O}_{2}$ can be increased to $15 \%$ (Trinh et al., 2018). The tests carried out by Khanjani et al. (2014) and Esteban (2014) in the Ali-Sadr Cave (Iran) and in the Ortigosa de Cameros Caves (Spain) used concentrations of $20 \%$ and $25 \%$ respectively, without any adverse effects being detected on the natural biota of the cave and on the speleothems. However, these applications must be done in specific cases, as the use of $\mathrm{H}_{2} \mathrm{O}_{2}$ may ultimately end up significantly discoloring the calcareous structures (Esteban, 2014).

It has been verified that even a $15 \%$ solution produces a more aggressive attack on the underlying carbonate rock than karstic water. Mulec (2012) specifies that the $15 \%$ solution of $\mathrm{H}_{2} \mathrm{O}_{2}$ without a buffer has a $\mathrm{pH}$ of 4 and could therefore lead to the dissolution of the limestone formations (Caneva et al., 2008). To resolve this, Faimon et al. (2003) propose saturating the preliminary hydrogen peroxide solution with calcium carbonate and adding a few fragments of limestone rock at least ten hours after its application. 
Once saturated, hydrogen peroxide is a chemical compound that provides good result and is more respectful with the environment than chlorated compounds, as it does not acidify groundwaters or generate unpleasant odors or harmful gases, and minimizes the aggression on the carbonate substrate (Grobbelaar, 2000; Faimon et al., 2003; Mulec, 2012).

In the Postojna Cave, Mulec and Glažar (2011) consumed an average of $1050 \mathrm{ml}$ of buffered hydrogen peroxide solution for every $10 \mathrm{~m}^{2}$ of treated surface in the cave. Each application took an average of 20 minutes. In successive treatments to prevent growths -normally two per year- the volume applied did not exceed the amount of $40 \mathrm{ml} / \mathrm{m}^{2}$ recommended by Mulec (2014). The amounts of chemicals used in the solution applied is $15 \%(\mathrm{v} / \mathrm{v})$ of hydrogen peroxide ( $\mathrm{pH} 7.0-7.5)$ containing $500 \mathrm{ml}$ of $\mathrm{H}_{2} \mathrm{O}_{2}$ at $30 \%, 75$ $\mathrm{ml}$ of $\mathrm{NaHCO}_{3} / \mathrm{Na}_{2} \mathrm{CO}_{3}$ buffer and $425 \mathrm{ml}$ of distilled water. Due to the instability of the buffered $\mathrm{H}_{2} \mathrm{O}_{2}$ the solution must be sprayed as soon as possible. In this case, it was applied 20 minutes after preparation, three consecutive times, with a week between each application.

Due to the strong oxidizing power of $\mathrm{H}_{2} \mathrm{O}_{2}$, several authors (Grobbelaar, 2000; Cigna, 2011a; Mulec \& Glažar, 2011; Hebelka, 2014) particularly emphasized the need to take special measures to protect the eyes and skin during spraying.

The efficiency of the hypochlorite may be due to the biocidal properties of the non-dissociated hypochlorous acid and the hypochlorite ion: both species damage cell membranes, are disseminated through the cell walls, alter enzymatic activity and may affect ion regulation (Claudi \& Evans, 1993; Claudi \& Mackie, 1994).

Faimon et al. (2003) therefore recommend that the show cave managers should opt for one of the following alternatives: (1) a rapid and effective elimination of lampenflora with hypochlorite, although it represents a negative burden for the cave environment; or 2) a more environmentally acceptable -albeit less effective- eradication technique, with hydrogen peroxide. However, Faimon et al. (2003) only tested the effectiveness of $\mathrm{H}_{2} \mathrm{O}_{2}$, and the comparison with sodium hypochlorite is based on an appreciation and not on quantitative data.

In some caves like the E1 Tesoro (Spain), studies have been done comparing hydrogen peroxide and sodium hypochlorite (Jurado et al., 2014). In this Spanish cave, both cleaning methods were very effective and maintained the walls and the speleothems clean for several months after the treatment. However, the administrators opted for treatment using hydrogen peroxide due to its harmlessness to the environment.

In the Cango Caves (South Africa), Grobbelaar (2000) suggested applying between $200-500 \mathrm{mg} / \mathrm{L}$ of $\mathrm{H}_{2} \mathrm{O}_{2}$ and washing and collecting the leachates after 5-30 minutes. If the lampenflora persists the washing must be repeated or combining it with the use of UV-C radiation. This procedure only needed to be used once every six months due to the low growth rate of the algae. It was also found that the use of $\mathrm{H}_{2} \mathrm{O}_{2}$ eliminated the fluff and part of the dirt introduced by visitors that had accumulated over time on the surface of the formations.

Hebelka (2014) have reached the conclusion that although its application is slower (as it is less effective than hypochlorites), hydrogen peroxide is the least harmful compound for underground habitats from the environmental point of view.

\section{Biocides}

Due to their toxicity, biocides (Diquat, Diuron, Atrazina, Simazina Karmex, etc.) are unsuitable for the treatment of lampenflora in show caves (Caumartin, 1977; Cigna, 2011a; Mulec \& Kosi, 2009; Mulec, 2012). However, there are some studies on the potential use of several herbicides such as Diquat and Diruon (Johnson, 1979) and Atrazine and Simazine (Grobbelaar, 2000) to eliminate lampenflora in show caves, although the latter are prohibited in the European Union: Simazine since 2003 and Atrazine since 2004 (European Biocides Directive 1998/8/EC). The results of further studies were disappointing and produced no apparent effect, as the greenish color persisted on the surface of the treated formations.

Nugari et al. (2009) tested the effectiveness of several biocides based on quaternary ammonium salts (Rocime 110, Preventol R80 and Umonium 38) on algae and cyanobacteria colonizing Byzantine paintings in the Crypt of the Original Sin (Matera, Italy). The products were effective in eliminating the lampenflora, but the colorimetric analysis revealed changes in the color of the substrate after treatment.

Other authors, cited by Mulec and Kosi (2009), have suggested the use of formaline (Cubbon, 1976; Caumartin, 1986; Merdenisianos, 2005), solutions of copper ammonia (Merdenisianos, 2005), butyl alcohol (Hill \& Forti, 1997) and formaldehyde at a dilution of between 0.5\% (Orial et al., 2009) and 5\% (Rajczy et al., 1997).

In all cases, del Rosal (2015) notes that any cleaning protocol based on the use of biocides must include the subsequent removal from the area of the resulting dead organic matter in order to avoid the massive colonization of the medium by fungal microorganisms as occurred in the Lascaux Cave (Lefèvre, 1974; Bastian et al., 2010; Martín-Sánchez, 2012).

Borderie et al. (2014a) noted that special attention should be paid to monitoring the treated surfaces, as the biocides can be easily transported to other areas and contaminate the cave environment.

Intense and periodic cleaning with biocides over a period of years may give rise to the displacement of the autochthonous microbiota in the cave, and its replacement by communities of microorganisms that are resistant to biocides (del Rosal, 2015). In Lascaux Cave, for example, the invasion of Fusarium solani species complex was treated with Benzalkonium choride from 2001 to 2004 . As a result, the indigenous microbial community was replaced by microbial populations selected by the biocide (Bastian et al., 2009).

\section{Natural Biocides}

The use of natural substances has been proposed recently to control de development of biofilms over 
natural substrate (Stupar et al., 2014; Sasso et al., 2016; Pfendler et al., 2018; Bruno et al., 2019). Among these substances, very different kind of compounds are mentioned such as glycoalkaloids, essential oils, Juglone, phenolic acids, flavonoids, terpenoids or alkaloids. These compounds show fungicide or insecticide properties, and some such as Juglone, can even interfere with the mechanism of photosynthesis and inhibit the growth of algae and it is, therefore, proposed to fight algae and cyanobacteria biofilms.

Any biocide, either natural or artificial, produces a similar effect: it selects resistant species and deeply modifies the original biota, therefore its use is questionable from an environmental point of view. Natural origin is not equal to less toxic. Toxicity depends on the chemical structure. In fact, most, if not all, biocides are toxic or otherwise polluting substances, and their degradation is frequently difficult, being persistent in the natural environment (Barresi et al., 2017). Moreover, when these substances are used inside a cave they will easily reach and pollute groundwater.

\section{Nanoparticles}

Many works have proven that metallic nanoparticles have powerful antimicrobial, antifungal and antialgae properties. Over the past few years, several experiments with these substances have been carried out for the mitigation of microbial colonization on stone surfaces specially in Cultural Heritage Restoration (SierraFernández et al., 2017). The main limitation for their use is that almost all heavy metals containing these particles are highly toxic for most lifeforms including humans. Among the most studied metals there are silver (Bellissima, 2013; Bellissima et al., 2014; Zarzuela et al., 2018), mixtures of consolitants, water repellents and copper nanoparticles (Pinna et al., 2012), and some metal oxides, particularly titanium dioxide (Bellissima, 2013; Ruffolo et al., 2017). Both silver and titanium are considered metals with little toxicity, but they are not harmless, especially in the form of nanoparticles (Raymond et al., 2009; Hadrup \& Lam, 2014). Their introduction in the natural environment must be avoided at any cost. Furthermore, those studies lack long-or mediumterm in situ experimentation, since they deal mainly with laboratory tests aimed to assess the products' efficacy (Ruffolo et al., 2017). However, if the studies on the toxicity of these particles in humans are scarce, those on the effect on natural fauna in caves are entirely missing.

\section{Liquid nitrogen}

There are few studies published on the use of liquid nitrogen as a method of eliminating lampenflora in show caves. A test was done in the El Tesoro Cave (Jurado et al., 2014), where liquid nitrogen applied with a brush represented a cleaning which combined mechanical elimination (thanks to the effect of the brush) with the congealment of the biological structures, which would theoretically represent an advantage. However, cleaning with this procedure was much less effective than with other chemical compounds (hydrogen peroxide and sodium hypochlorite), as it failed to totally eliminate the green patches. The complications involved in its transport, execution and handling, mean this treatment is not recommended.

\section{Environmental control methods}

\section{Lighting control}

In the natural cave environment, whether a show cave or not, adequate levels of moisture and nutrients are almost always achieved for the development of the biofilms that form the lampenflora (Johnson, 1979), and the limiting factor for the development of these communities is the lack of light. For example, Martinez and Asencio (2010) showed that in the Gelada Cave (Spain) the main stress factor for the biofilms was the lack of light, followed by moisture deficit, lack of nutrients and finally, temperature variations.

As lighting is precisely the factor that is easiest to control, managers seek to limit the development of lampenflora communities by modifying the design and the technology of the lighting system (Olson, 2006). The aim is to reduce the amount and intensity of the light emitted and adopt a light spectrum whose emission range does not coincide with the wavelengths that favor the growth of lampenflora (Johnson, 1979; Smith \& Olson, 2007).

From a quantitative point of view, a discontinuous lighting regime theoretically restricts the growth of lampenflora, as plants require a series of chemical and physiological changes to adapt to different phases of light and darkness, which involves an extra energy input (Aley, 2004).

The simplest way of restricting the growth of lampenflora in show caves is by reducing the duration of the lighting periods, keeping the lights on only when visitors are present, which also achieves a reduction in the energy released into the environment and lowers electricity costs (Grobbelaar, 2000; Mulec \& Kosi, 2009; Cigna, 2011a; del Rosal, 2015). Planina (1974) estimates that lampenflora cannot develop if the illumination in the cave does not exceed 100 hours a year.

Lampenflora communities can survive and reproduce in conditions of low light and even tolerate its absence for varying periods of time (Dalby, 1966; Martincic et al., 1981; Mulec, 2005; Glime, 2007). Cigna (2011a) indicates that although the reduction in light for a prolonged interval of time (for example, a month) counteracts the proliferation of photosynthetic organisms in caves, it may favor the dissemination of other resistant organisms (generally cyanobacteria) due to reduced competition (Giordano et al., 2001; Montechiaro \& Giordano, 2006).

The intensity of the light may be decreased by using less powerful lamps that emit the smallest possible amount of heat (Gurnee, 1994) or by establishing a safety distance between the light source and the cave surface. Cigna (2011a) indicates that a distance of approximately $1 \mathrm{~m}$ should be safe, whereas ByoungWoo (2002) recommends extending this to at least $2 \mathrm{~m}$.

Another option is to use disperse illumination (Mulec \& Kosi, 2009), as lampenflora does not develop, or 
develops very slowly under diffuse lighting methods, as occurs in the speleotherapy centre for patients with pulmonary ailments at the Sezana Hospital (Slovenia) (Mulec, 2005). Olson (2006) suggests that diffuse illumination can be supplied by corridor lamps directed towards the path surface.

The level of lighting must be sufficient for visitors to see the path and the low ceilings clearly, so they can enjoy the cave (Grobbelaar, 2000; Olson, 2006). However, Mulec and Kosi (2009) invite managers not to show off the caves in the brightest and most highly illuminated conditions possible, but to opt for a level of lighting that allows the natural or cultural heritage to remain partly concealed or in half light, so its beauty can be admired as it was at the beginnings of underground tourism.

From a qualitative point of view, when designing the lighting system, a light spectrum should be selected that is minimally absorbed by the photosynthetic pigments (Olson, 2006). This is done for example by using a green light (around $530 \mathrm{~nm}$ ) as recommended by Harris (1981) in Mammoth Cave or by Oostthuizen (1981) and Grobbelaar (2000) in the Cango Caves. However, several authors (Aley, 2004; Olson, 2006; Mulec, 2014) say that for aesthetic reasons green lighting is a somewhat impracticable strategy and is normally rejected by the administrators of show caves as it does not give the underground environment a natural appearance. The use of green light would not be so successful against organisms that can modify their accessory pigments (Roldán et al., 2006).

Imprescia and Muzi (1984) and Olson (2002) have opted for the use of yellow light (around $580 \mathrm{~nm}$ ) as a possible alternative. Lampenflora communities do not strongly absorb this type of light (Aley, 2004; Mulec, 2012) and the visual impact is minimal, giving the cave a natural appearance, as the walls are often bathed in earthy and yellowish tones. The human eye is also much more sensitive to yellow light than to the red and blue wavelengths that feed photosynthesis (Olson, 2006). For example, in the El Tesoro Cave, LED-type yellow light points were installed with an emission range of $590 \mathrm{~nm}$, with good results (Jurado et al., 2014).

Del Rosal (2015) analyzed the emission spectra of the photosynthetic organisms in the Nerja Cave by monitoring the physiological state and the photoacclimatization processes of the biofilms. She identified through the pigments the most unfavorable wavelength range for their development. A wavelength of around $560 \mathrm{~nm}$ was proposed as the most appropriate for the design of the new lighting system.

With regard to the type of lighting, halogen lamps are often still used in many show caves and other underground spaces open to the public. However, they are gradually being replaced by other types of lighting as they do not preserve the environmental conditions of the cave, but increase the temperature and decrease the environmental humidity when they are lit (Cigna, 2011a; Mulec, 2014; D’Agostino et al., 2015).

High- and low-pressure sodium steam lamps and LED-diode lamps are a more appropriate option, as they have less impact on the atmosphere in the cave, and the emissions spectra of these lamps are largely located in the chlorophyll absorption peaks (Merdenisianos, 2005; Olson, 2006).

The problem with sodium steam lamps is that they take some time to achieve their total brightness, and repeatedly turning them on and off significantly reduces their useful life (Olson, 2006). Kartalis and Mais (2001) observed that in the Alistrati Cave (Greece), low-pressure sodium steam lamps were not active in preventing the development of lampenflora. Although LED lamps are not so bright, they have numerous advantages: they have a narrow emissions spectrum and can be adjusted according to need, they light immediately, are very energy efficient, emit very little heat, produce no noise and have a very long useful life (up to 100,000 hours or ten years of continuous use) (Olson, 2006; Toomey et al., 2009).

These characteristics have led numerous caves around the world to opt to install LED illumination at the start of the $21^{\text {st }}$ century. Mulec and Kosi (2009) and Cigna (2011a) cite the work of Olson (2002) in Mammoth Cave as an example, where it was successfully demonstrated that the development of lampenflora could be controlled through the use of LED illumination. An emission range was used of 595 $\mathrm{nm}$ (yellow) with an intensity of $49.5 \mathrm{~lx}$, preventing the growth of the lampenflora for a year and a half after its installation.

Several authors (Johnson, 1979; Mulec \& Kosi, 2009; Cigna, 2011a; Hebelka, 2014; Ramírez-Trillo \& González-Ríos, 2014), have suggested implementing a lighting system divided into two differentiated sectors or circuits:

- $1^{\text {st }}$ circuit - illumination of the visitors' route on paths and platforms to allow their safe passage through the cave.

- $2^{\text {nd }}$ circuit - scenic or artistic illumination to highlight the most spectacular formations. This can be turned on manually with switches activated by the guides during the visit, or they can be programmed to turn on for a limited period of time only when visitors pass nearby.

The first circuit must be equipped with emergency lighting batteries that guarantee safety in the case of an electrical failure, and the second circuit must be provided with infra-red sensors (or similar) that react to movement. Each of these circuits must have control units and automatic switching that operate separately and independently.

It's also very effective re-orienting or relocating the lights in areas susceptible to being colonized, avoiding the illumination of substrates covered by mud, sedimentary or earthy structures and damp surfaces (Rajczy, 1989; Mulec, 2012; Ramírez-Trillo \& González-Ríos, 2014). Mulec and Kosi (2009) also note that the placement of lamps in areas with a strong air circulation should be reconsidered due to the possible increase in the dispersion of the lampenflora.

A dramatic change in the lighting of areas colonized by photosynthetic biofilms could lead to the massive death of these organisms, and therefore to an increase in organic matter in the environment (del 
Rosal, 2015). This would represent an important source of nutrients, and possibly cause a large-scale development of fungi generating a situation similar to what occurred in the Lascaux Cave. To avoid this the author proposes gradually replacing the illumination in a controlled way, and previously cleaning any intensely colonized speleothems in order to reduce the amount of organic matter.

Finally, Olson (2006) proposes the use of portable electric torches as an alternative. No problems with lampenflora have been reported in caves illuminated with hand-held or helmet-mounted torches, and many of the impacts related with the installation of a lighting system could be avoided. However, the author also concedes that in tourist caves with a high influx of public, the logistics of maintaining optimal operating conditions for hundreds of torches renders this idea somewhat impracticable. However, on a small scale, in caves where the influx of public is limited to small groups divided in shifts, this solution has been found to be the most effective, as is the case of the Castanar de Ibor Cave.

\section{Ultraviolet radiation (UV-C)}

Ultraviolet light is a form of electromagnetic radiation with a wavelength located between visible light and $\mathrm{x}$-rays. It is divided into three categories based on its energy capacity and its effects on living matter: UV-A (400-315 nm), UV-B (315-280 nm) and UV-C (280$200 \mathrm{~nm}$ ) (Yin et al., 2013).

$\mathrm{UV}-\mathrm{C}$ radiation, unlike $\mathrm{UV}-\mathrm{A}$ and $\mathrm{UV}-\mathrm{B}$, is completely filtered by the ozone layer and is considered to be the most harmful to living beings due to its highly energetic photons. Its strong germicidal effect causes irreversible damage to photosynthetic organisms (Adhikary \& Sahu, 1998; Danon \& Gallois, 1998; Jayakumar et al., 1999; Zvezdanović et al., 2009) and, in the case of algae and cyanobacteria, it has been demonstrated that this type of radiation has the potential to cause serious damage in the cell constituents involved in photosynthesis (Alam et al., 2001; Moharikar et al., 2006; Sakai et al., 2007; Tao et al., 2010, 2013; Ou et al., 2011, 2012) (works cited in Borderie et al., 2014a). It is therefore used mainly as biocidal and disinfectant lighting in several sectors such as medicine, the food industry and water treatment (Borderie et al., 2014a).

However, the use of UV-C radiation has also been incorporated in the field of conservation of heritage materials. The first to propose this alternative use was Dobat (1963) from his own observations in the Lascaux Cave (cited in Lefèvre, 1974). Among other measures, Dobat proposed the use of UV radiation as substitute for chemical products for the disinfection of algae. Subsequently, Van Der Molen and others (1980) successfully developed a mobile ultraviolet unit (MUVU) to treat walls colonized by algae and cyanobacteria in the Church of St. Stephanus in Pilsum (Germany).

However, exposure to $\mathrm{UV}-\mathrm{C}$ radiation is not a suitable procedure to combat the proliferation of microorganisms on organic matter, as just as with living organisms, organic matter (paper, wood, textiles, etc.) can be damaged by UV-C rays (Caneva et al., 2008).

In addition to Dobat (1963) other authors have proposed the use of UV-C radiation to limit and control the proliferation of photosynthetic microorganisms in the specific sector of show caves, such as for example in the Grotta Gigante (Italy) (Fabbricatore, 2009), where the research by Borderie and his collaborators deals more extensively with this method and its effects (Borderie, 2014; Borderie et al., 2011, 2012, 2014a, b, and c). These authors worked in the Moidons Cave (France) with the aim of assessing the efficiency of a germicidal treatment with UV-C applied to different types of biofilms.

The samples were irradiated with a UV-C box containing two $11 \mathrm{~W}$ lamps each with a wavelength of $254 \mathrm{~nm}$ and treated glass to avoid the formation of ozone. In each treatment the lamps alternated periods when they were on (30 $\mathrm{min})$ and off $(15 \mathrm{~min})$ for $12 \mathrm{~h}$ (corresponding to 8 hours of exposure). The irradiation was done at night when the cave was closed to visitors, and the UV-C box was hermetically sealed with black plastic to avoid UV-C dispersion around the treated area. A photoradiometer was placed in the box to measure the effective irradiation. Each biofilm treated received a dose of $180 \mathrm{~kJ} \mathrm{~m}^{-2}$. The treatment was able to kill the microorganisms and induce the degradation of the chlorophyll pigments responsible for the green appearance. This approach is very promising, as many chemical products are capable of killing the organisms, but fail to destroy the pigments so the greenish color persists in the substrate. However, treatment with UV-C did not always completely eliminate the green color, as its efficiency largely depends on the thickness of the biofilm: the underlying cells benefited from the protective shield of the superimposed cells, which absorbed the radiation. The application of two 8-hour UV-C treatments instead of one would have been sufficient to induce the complete whitening of a biofilm of thick green algae.

Another advantage of this method is that its use does not cause a negative impact on the materials exposed, nor does it generate any toxic residual element in the environment. The monitoring of the biofilms showed that the treatment was effective for at least one year, but the biological colonization did not cease, and the greening phenomena once again reappeared 16 months later.

Given that each cave is characterized by its own climate parameters, the results obtained in the Moidons Cave cannot be directly transferred to other sites. This cave is open to the public only six months a year (from April to October), so the absence of light in the closed period helps contain the colonization of algae, with no dynamic proliferation. It can be assumed that the recolonization time after UV treatment in the Moidons Cave (approximately one year) is probably longer than in other caves that are open all year round.

UV-C treatments can easily be applied in accessible areas such as on floors, walls and speleothems, but this method has some limitations, particularly in the case of remote areas (for example ceilings), and 
indicate that new engineering developments are required to improve the effectiveness of the treatment and to limit energy expenditure (for example, through the use of UV-C LEDs).

Other authors have been less enthusiastic about this method. For example, Kermode (1975) and Johnson (1979) carried out several experiments with ultraviolet lamps to prevent the growth of lampenflora in the Waitomo caves (New Zealand), effective results were only obtained in the affected substrate using a $30 \mathrm{~W}$ germicidal lamp at a distance of $50-70 \mathrm{~cm}$ from the light source, when lampenflora generally tends to be located at distances of over $3 \mathrm{~m}$. This would require the use of more powerful lamps, or the need to collect the existing carcasses in areas near the affected substrate. In any case the high costs of the work would render this method of control somewhat unprofitable.

Hebelka (2014) also identifies this problem in caves located in the Moravian Karst (Czech Republic) and recommends applying this method in smaller caves. Another disadvantage cited by the author is that in areas with a proliferation of stalactites and narrow cracks, shadows are generated that may reduce or significantly inhibit the effect of UV radiation.

Grobbelaar (2000) tested the efficacy of UV-C lamps on the algae that thrive in the Cango Caves (South Africa), both in laboratory cultures and in the caves themselves. He concluded that this type of radiation is effective for killing and whitening the algae, and proposed a treatment in which the use of UV-C is combined with hydrogen peroxide. However, he also states that this process requires considerable time, as the lamps had to be turned off once the visitors accessed the caves. It should also be considered that UV light triggers the breakdown of peroxide, so both treatments cannot therefore act simultaneously.

Finally, Mulec (2014) indicates that UV-C irradiation is not a suitable procedure for caves unless due precautions are taken, particularly in places populated by fauna.

\section{High temperatures}

Kermode (1975) and Johnson (1979) suggested the use of low-pressure steam or hot water instead of cold water to eliminate lampenflora communities and clean the walls in the Waitomo Cave.

Tests and prior experiences have shown that these methods are effective, with the advantage that they have a highly localized effect and do not produce toxic residues (Aley, 1972). However, their repeated use may erode some fragile surfaces and this method also has some practical drawbacks, as it requires bulky equipment and continued access to a water and energy supply. Finally, this method is not fast, as it takes at least ten minutes to treat each square meters of surface area.

\section{Biological control}

One possible way of restricting the growth of lampenflora (Mulec \& Kosi, 2009) is the use of antagonistic organisms such as genetically modified viruses. However, the authors acknowledges that the introduction of exotic species for the control of other species often has unexpected consequences and can lead to far worse environmental problems. In any case these methods would kill the algae but leave a remnant of organic matter that would serve as a substrate for other organisms, mainly fungi.

\section{CONCLUSIONS}

The control of lampenflora communities poses two urgent questions: (1) how to prevent its growth, and (2) once it is established, how to eliminate it without damaging the substrate. Based on the advantages, drawbacks, limitations and recommendations of each method described in this work and synthesized in Table 4, it can be concluded that in spite of the variety of control methods available, no definitive solution has yet been found (Fig. 3).

Perhaps the main problem concerning research in lampenflora control is that in spite of the great number of experiments developed for over 40 years, many of the methods for assessing success were arbitrary, qualitative and non-replicable. There are no normalized methods to measure the efficacy of a lampenflora removing process and, more importantly, it is not possible to compare the results of different authors.

A similar problem has been observed regarding the information of the effects of cleaning treatments, particularly chemical methods, on the natural fauna of caves. The starting assumption is always that the use of products that are toxic in other environments will be also toxic for cave inhabitants, but there are almost no research where toxicity or unfavorable effects are measured quantitatively.

The most popular product for cave cleaning is sodium hypochlorite. However, there is no experimental study that sheds light on which hypochlorite concentrations are effective to kill the biofilm, which hypochlorite concentrations are effective to ensure a longer duration of the cleaning effect, and which hypochlorite concentrations are effective to achieve a whitening effect. Meyer et al. (2017) suggest concentrations 10 times lower than those usually applied are fully effective. It is essential to develop a methodology allowing for quantification and comparison between methods.

In the field of monument restoration, catacombs, stone walls, etc, new methods for biofilms removal through the application of biocides and metallic nanoparticles are being tested. In spite of the likely toxicity of these compounds, their use, effectiveness and real impact in caves should be studied.

The design of actions intended to prevent and -where necessary-combat the processes of biodeterioration caused by lampenflora requires three multidisciplinary actions:

- An integrated analysis of these biological communities to determine their diversity, physiology and relation with the colonized substrate.

- The implementation of combined methods of prevention and elimination. Current prevention 


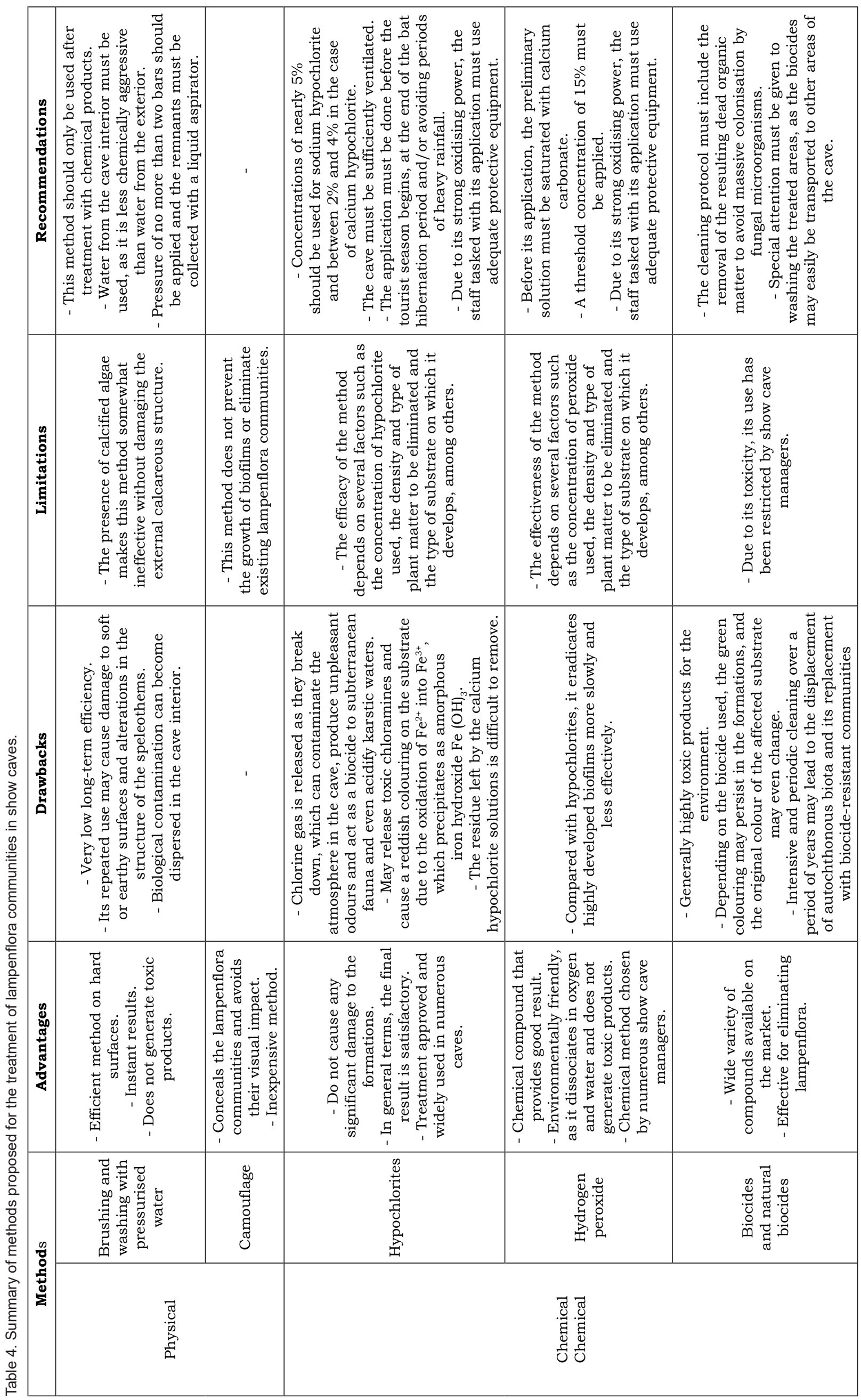




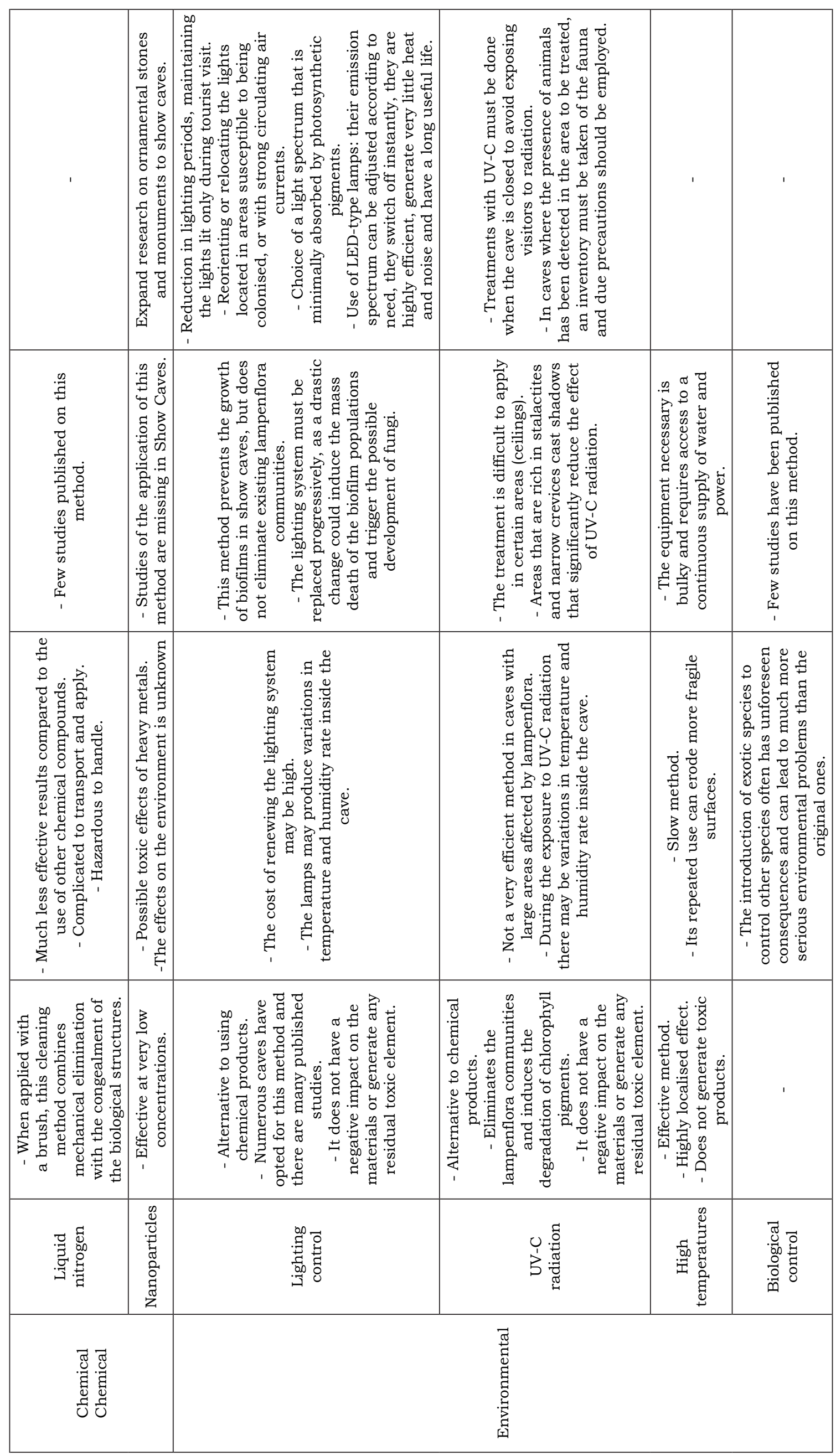




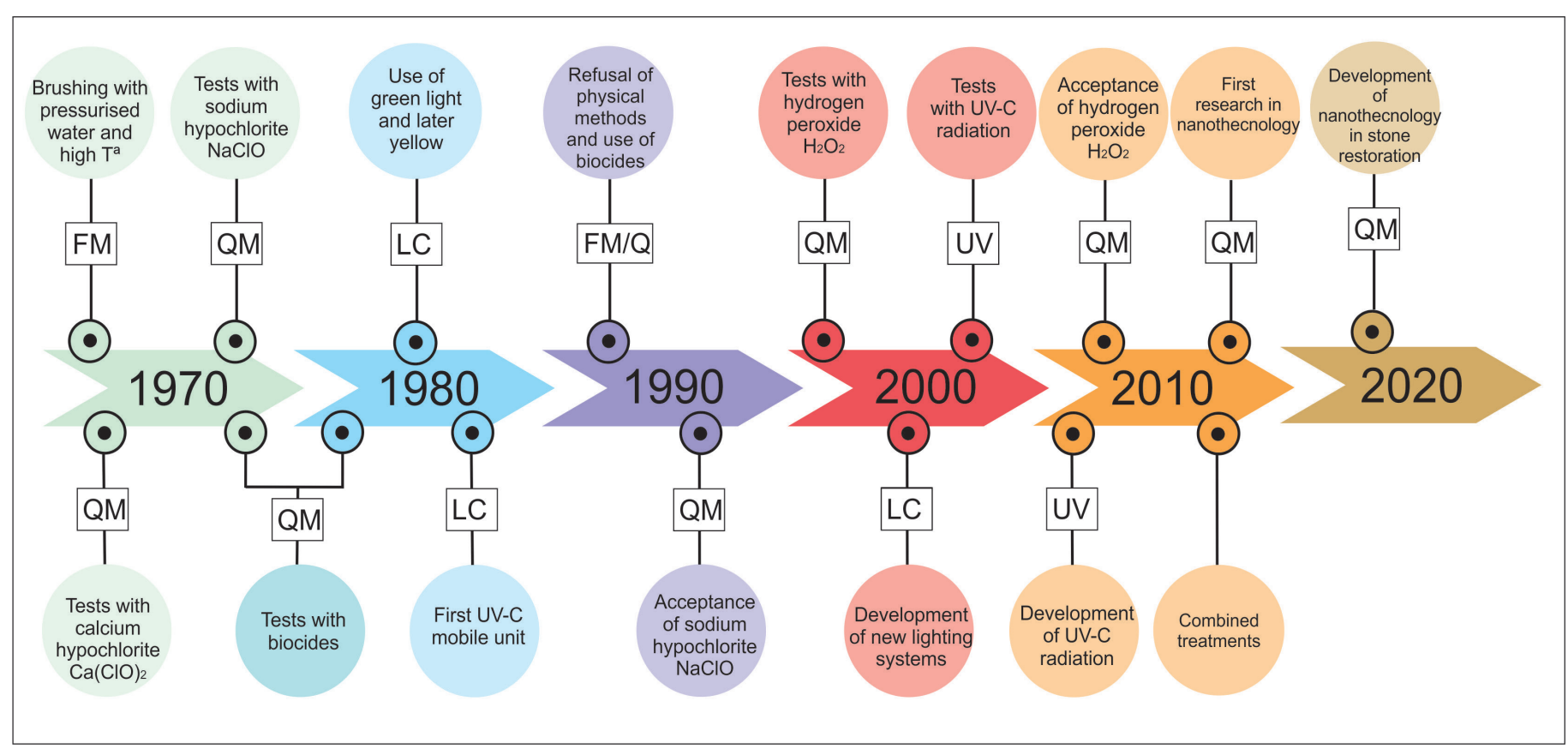

Fig. 3. Time line showing the different methods proposed since the 1970s through to the present day to tackle lampenflora in show caves.

FM: physical method; QM: chemical method; LC: light control; UV: ultra violet.

methods are based mainly on strict control of the lighting, reducing the duration of lighting periods and using inefficient wavelengths to restrict the process of photosynthesis. The most widespread method of elimination is the use of chemical products, specifically hypochlorites and hydrogen peroxide. However, in certain situations, other methods described in previous sections cannot be ruled out, including: UV-C radiation, brushing and others.

- In parallel it is necessary to determine the evolution of these organisms before and after carrying out these control actions.

Finally, from a management point of view it is recommended to adapt and follow current international guidelines. As described by Cigna (2011b), in 1997 the World Commission on Protected Areas at the International Union for Conservation of Nature (UICN) published a leaflet (Watson et al., 1997) with a series of guidelines for the protection of karstic elements and wild caves. The principles included in this publication served as a good foundation, but it was considered necessary to create guidelines aimed specifically at show caves. After many recommendations and suggestions received over a period of 20 years, a final text was agreed at the seventh International Congress of the International Show Caves Association (ISCA) held in the Jenolan Caves in November 2014, with the title "Recommended International Guidelines for the Development and Management of Show Caves", available at the following address: www.uis-speleo.org.

\section{ACKNOWLEDGEMENTS}

This work has been developed as part of the activities in the Research in Geological Resources Department at the Spanish Geological Survey, and was funded through project GESTEC 2547 (2017-2018) entitled: "Viability analysis and development of a patent for a physical-chemical treatment for carbonate structures affected by lampenflora". We would like to thank the reviewers for the time and effort invested in this paper. Their suggestions has substantially improved the first version of it.

\section{REFERENCES}

Adhikary S.P. \& Sahu J.K., 1998 - UV protecting pigment of the terrestrial cyanobacterium Tolypothrix byssoidea. Journal of Plant Physiology, 153: 770-773.

https://doi.org/10.1016/S0176-1617(98)80233-2

Alam M.Z.B., Otaki M., Furumai H. \& Ohgaki S., 2001 Direct and indirect inactivation of Microcystis aeruginosa by UV-radiation. Water Research, 35: 1008-1014. https://doi.org/10.1016/S0043-1354(00)00357-2

Albertano P., 1993 - Epilithic algal communities in hypogean environments. Giornale Botanico Italiano, 127 (3): 386392. https://doi.org/10.1080/11263509309431020

Albertano P., Bruno L., D’Ottavi D., Moscone D. \& Palleschi G., 2000 - Effect of photosynthesis on $p H$ variation in cyanobacterial biofilms from Roman catacombs. Journal of Applied Phycology, 12: 379-384. https://doi.org/10.1023/A:1008149529914

Albertano P. \& Bruno L., 2003 - The importance of light in the conservation of hypogean monuments. In: Saiz-Jiménez C. (Ed.), Molecular biology and cultural heritage. Taylor and Francis, London, p. 171-177. https://doi.org/10.1201/9780203746578

Albertano P., 2012 - Cyanobacterial biofilms in monuments and caves. In: Whitton B.A. (Ed.), Ecology of cyanobacteria. II: their diversity in space and time. Springer Dordrecht, Netherlands, p. 317-343. https://doi.org/10.1007/978-94-007-3855-3

Aley T., 1972 - Control of unwanted plant growth in electrically lighted caves. Caves and Karst, 14 (5): 33-35.

Aley T., 2004 - Tourist caves: Algae and lampenflora. In: Gunn J. (Ed.), Encyclopedia of caves and karst science. Taylor \& Francis, New York, p. 1568-1570. https://doi.org/10.4324/9780203483855

Aley T., Aley C. \& Rhodes R., 1984 - Control of exotic plant growth in Carlsbad Caverns, New Mexico. Proceedings of the 1984 National Cave Management Symposium. Missouri Speleology, 25 (1-4): 159-171. 
Aleya L., 1991 - The concept of ecological succession applied to a eutrophic lake through the seasonal coupling of diversity index and several parameters. Archiv für Hydrobiologie, 120 (3): 327-344.

Aleya L., Desmolles F., Michard M., Bonnet M. \& Devaux J., 1994 - The deterministic factors of the Microcystis aeruginosa blooms over a biyearly survey in the hypereutrophic reservoir of Villerest (Roanne, France). Archiv für Hydrobiologie, 4: 489-515.

Alpert P., 2006 - Constraints of tolerance: why are desiccation-tolerant organisms so small or rare?. The Journal of Experimental Biology, 209: 1575-1584. https://doi.org/10.1242/jeb.02179

Annous B.A., Fratamico P.M. \& Smith J.L., 2009 Quorum sensing in biofilms: Why bacteria behave the way they do?. Journal of Food Science, 74: 24-27. https://doi.org/10.1111/j.1750-3841.2008.01022.x

Anon J., 1976 - The "clean" caves. Panorama: Journal of Ansett Airlines of Australia, 18 (6): 1.

Asencio A.D. \& Aboal M., 2001 - Biodeterioration of wall paintings in caves of Murcia (SE Spain) by epilithic and chasmoendolithic microalgae. Algological Studies, 103: 131-142.

https://doi.org/10.1127/algol stud/103/2001/131

Ash J., Ashton K., Bonny A., Dimond P., Hendy C., May B., Nelson C., Wheeler D. \& Williams P., 1975 - Report on the conservation of Waitomo caves. New Zealand Speleological Bulletin, 5 (93): 373-396.

Barresi G., Cammarata M. \& Palla F., 2017 - Biocide. In: Palla F. \& Barresi G. (Eds.), Biotechnology and conservation of cultural heritage. Springer International Publishing Switzerland, p. 49-65.

https://doi.org/10.1007/978-3-319-46168-7

Bastian F. \& Alabouvette C., 2009 - Lights and shadows on the conservation of a rock art cave: The case of Lascaux Cave. International Journal of Speleology, 38: 55-60. https://doi.org/10.5038/1827-806X.38.1.6

Bastian F., Alabouvette C., Jurado V. \& Saiz-Jiménez C., 2009 - Impact of biocide treatments on the bacterial communities of the Lascaux Cave. Naturwissenschaften, 96: 863-868.

https://doi.org/10.1007/s00114-009-0540-y

Bastian F., Jurado V., Novakova A., Alabouvette C. \& Saiz-Jiménez C., 2010 - The microbiology of Lascaux Cave. Microbiology, 156: 644-652.

https://doi.org/10.1099/mic.0.036160-0

Bellezza S., Albertano P., De Philippis R. \& Paradossi G., 2006 - Exopolysaccharides of two cyanobacterial strains from Roman Hypogea. Geomicrobiology Journal, 23: 301-310.

https://doi.org/10.1080/01490450600761904

Bellissima F., 2013 - Investigation on the use of titanium dioxide and silver nanoparticles to inhibit biodeterioration of stone. Unpublished Doctoral Thesis, Chemistry Department, University of Florence, 188 p.

Bellissima F., Bonini M., Giorgi R., Baglioni P., Barresi G., Mastromei G. \& Perito B., 2014 - Antibacterial activity of silver nanoparticles grafted on stone surface. Environmental Science and Pollution Resources, 21: 13278-13286.

https://doi.org/10.1007/s11356-013-2215-7

Bertolani M., Cigna A., Maccio S., Morbidelli L. \& Sighinolfi G., 1991 - The karst system "Grotta grande del vento -Grotta del Fiume" and the conservation of its environment. In: Sauro U. (Ed.), Proceedings of the International Conference on Environmental changes in karst areas. Dipartimento di Geografia, Università of Padova, p. 289-298.

Bickford E.D. \& Dunn S., 1972 - Lighting for plant growth. The Kent State University Press. Kent, 221 p.
Bočić N., Lukić A. \& Opapačić V.T., 2006 - Management models and development of showcaves as tourist destinations in Croatia. Acta Carsologica, 35 (2): 13-21. https://doi.org/10.3986/ac.v35i2-3.224

Bolivar F.C. \& Sánchez-Castillo P.M., 1997 Biomineralization processes in the fountains of the Alhambra, Granada, Spain. International Biodeterioration \& Biodegradation, 40: 205-215. https://doi.org/10.1016/S0964-8305(97)00042-5

Bonwick J., Ellis R. \& Bonwick M., 1986 - Cleaning, restoration and redevelopment of show caves in Australia. Proceedings of the $9^{\text {th }}$ International Congress of Speleology, Budapest, Hungary, p. 221-223.

Borderie F., 2014 - Utilisation du rayonnement UV-C comme méthode alternative aux produits chimiques dans la lutte et le controle de la prolifération des micro -organismes sur les matériaux du patrimoine. Thèse. L'Université de Franche-Comté, 310 p.

Borderie F., Alaoui-Sehmer L., Raouf N., Bousta F., Orial G., Rieffel D. \& Alaoui-Sossé B., $2011-U V-C$ irradiation as a tool to eradicate algae in caves. International Biodeterioration \& Biodegradation, 65: 579 -584.

https://doi.org/10.1016/j.ibiod.2011.02.005

Borderie F., Alaoui-Sehmer L., Bousta F., Orial G., Rieffel D., Richard H. \& Alaoui-Sossé B., 2012 - UV irradiation as an alternative to chemical treatments: a new approach against algal biofilms proliferation contaminating building facades, historical monuments and touristic subterranean environments. In: Krueger D. \& Meyer H. (Eds.), Algae: Ecology, economic uses and environmental impact. Nova Science Publishers, New York, p. 1-28.

Borderie F., Alaoui-Sossé B. \& Aleya L., 2014a-Heritage materials and biofouling mitigation through UV-C irradiation in show caves: state -of-the -art practices and future challenges. Environmental Science and Pollution Research, 6 (22): 4144-4172.

https://doi.org/10.1007/s11356-014-4001-6

Borderie F., Alaoui-Sehmer L., Bousta F., Alaoui-Sossé B. \& Aleya L., 2014b - Cellular and molecular damage caused by high UV-C irradiation of the cave-harvested green alga Chlorella minutissima: Implications for cave management. International Biodeterioration \& Biodegradation, 93: 118-130.

https://doi.org/10.1016/j.ibiod.2014.05.014

Borderie F., Tête N., Cailhol D., Alaoui-Sehmer L., Bousta F., Rieffel D., Aleya L. \& Alaoui-Sossé B., $2014 c$ - Factors driving epilithic algal colonization in show caves and new insights into combating biofilm development with UV-C treatments. Science of the Total Environment, 484: 43-52.

https://doi.org/10.1016/j.scitotenv.2014.03.043

Bottrell S., 1996 - Organic carbon concentration profiles in recent cave sediments: Records of agricultural pollution or diagenesis?. Environmental Pollution, 91: 325-332. https://doi.org/10.1016/0269-7491(95)00064-X

Bruno L. \& Valle V., 2017 - Effect of white and monochromatic lights on cyanobacteria and biofilms from Roman Catacombs. International Biodeterioration \& Biodegradation, 123: 286-295.

https://doi.org/10.1016/j.ibiod.2017.07.01

Bruno L., Rugnini L., Spizzichino V., Canave L., Canini A. \& Ellwood N., 2019 - Biodeterioration of Roman hypogea: the case study of Catatombs of SS. Marcellino and Prieto (Rome, Italy). Annals of Microbiology, in press. https://doi.org/10.1007/s13213-019-01460-Z

Büdel B`., Darienko T., Deutschewitz K., Dojani S., Friedl T., Mohr K.I., Salisch M., Reisser W. \& Weber B., 2009 - Southern African biological soil crusts are ubiquitous 
and highly diverse in drylands, being restricted by rainfall frequency. Microbial Ecology, 57 (2): 229-247. https://doi.org/10.1007/s00248-008-9449-9

Byoung-Woo K., 2002 - Ecological study for the control of green contamination in Korean show caves. Proceedings of the $4^{\text {th }}$ Samcheok International Cave Symposium. The Sustainable Management of Cave: "Academic and Policy Implications". Samcheok City, South Korea. Kangwon Development Research Institute, p. 74-76.

Caneva G., Nugari M.P. \& Salvadori O., 2008 - Plant biology for cultural heritage: biodeterioration and conservation. Getty Conservation Institute, Los Angeles, $408 \mathrm{p}$.

Carrasco F., 1993 - Geología de la Cueva de Nerja. Trabajos sobre la Cueva de Nerja, $n^{\circ} 3$. Patronato de la Cueva de Nerja, Málaga, España, 354 p.

Caumartin V., 1977 - Conservation des cavernes aménagées. Resultats obtenus dans quelques pays d'Europe occidentale. In: Ford T.D. (Ed.), Proceedings of the $7^{\text {th }}$ International Congress of Speleology, University of Leicester, p. 96-98.

Caumartin V., 1986-La conservation des concrétions dans les caverns aménagées. In: Pere P. (Ed.), Proceedings of $9^{u}$ Congreso Internacional de Espeleología, Barcelona, p. 223-225.

Caumartin V., 1994 - Reflexion sur la conservation des grottes amenagées pour la visite touristique. ANECAT. Paris.

Cennamo P., Marzano C., Ciniglia C., Pinto G., Cappelletti P., Caputo P. \& Pilio A., 2012 - A survey of the algal flora of anthropogenic caves of Campi Flegrei (Naples, Italy) archeological district. Journal of Cave and Karst Studies, 74 (3): 243-250. https://doi.org/10.4311/2011JCKS0194

Cennamo P., Caputo P., Giorgio A., Moretti A. \& Pasquimo N., 2013 - Biofilms on Tuff Stones at Historical Sites: Identification and Removal by Nonthermal Effects of Radiofrequencies. Microbial Ecology, 66: 659-668. https://doi.org/10.1007/s00248-013-0247-7

Chang T.P. \& Chang-Schneider H., 1991 - Algen in vier suddeutschen Hohlen. Berichte der Bayerischen Botanischhen Gesellschaft, 62: 221-229.

Ciferri O., 1999 - Microbial degradation of paintings. Applied and Environmental Microbiology, 65 (3): 879-885. https://aem.asm.org/content/65/3/879/article-info

Cigna A., 2011a - The problem of Lampenflora in Show Caves. In: Bella P. \& Gazik P. (Eds.), Proceedings of the $6^{\text {th }}$ ISCA Congress. Slovak Caves Administration, Slovakia, p. 201-205.

http://www.i-s-c-a.com/resource/82-6th-iscacongress-cigna-problem-of-lampenflora-in-show-caves

Cigna A., 2011b - Show cave development with special references to active caves. Tourism and Karst Areas, 4 (1): $7-16$.

http://www.cavernas.org.br/ptpc/tka v4 n1 007-016.pdf

Cigna A., 2012 - Show caves. In: White W.B. \& Culver D.C. (Eds.), Encyclopedia of caves. Elsevier, Amsterdam, p. 690-697.

https://doi.org/10.1016/C2010-0-64793-6

Cigna A. \& Burri E., 2000 - Development, management and economy of show caves. International Journal of Speleology, 29: 1-27.

https://doi.org/10.5038/1827-806X.29.1.1

Cigna A. \& Forti P., 2013 - Caves: the most important geotouristic feature in the world. Tourism and Karst Areas, 6 (1): 9-26.

Claudi R. \& Evans D.W., 1993 - Chemical addition strategies for zebra mussel (Dreissena polymorpha) control in once -through service water systems. In:
Nalepa T.F. \& Schloesser D.W. (Eds.), Zebra mussels: Biology, impacts, and control. Lewis Publishers, Boca Raton, p. 563-573.

Claudi R. \& Mackie G.L., 1994 - Practical manual for zebra mussel monitoring and control. Lewis Publishers, Boca Raton, 810 p.

Claus G., 1962 - Data on the ecology of the algae of Peace Cave in Hungary. Nova Hedwigia, 4 (1): 55-79.

Claus G., 1964 - Algae and their mode of life in the Baradla Cave at Aggtelek II. International Journal of Speleology, 1: 13-17.

https://doi.org/10.5038/1827-806X.1.1.2

Cooksey K.E., 1992 - Bacterial and algal interaction in biofilms. In: Melo L.F., Bott T.R., Fletcher M. \& Capdeville B. (Eds.), Biofilms science and technology. Kluwer Academic Press, p. 163-173.

https://doi.org/10.1007/978-94-011-1824-8_16

Costerton J.W., Stewart P.S. \& Greenberg E.P., 1999 - Bacterial biofilms: a common cause of persistent infections. Science, 284: 1318-1322.

https://doi.org/10.1126/science.284.5418.1318

Crispim C.A. \& Gaylarde C.C., 2005 - Cyanobacteria and biodeterioration of cultural heritage: A review. Microbial Ecology, 49: 1-9. https://doi.org/10.1007/s00248-003-1052-5

Cubbon B.D., 1976 - Cave flora. In Ford T.D. \& Cullingford C.H.D. (Eds.), The science of speleology. Academic Press, London, p. 423-452.

Cutler N.A., Viles H.A., Ahmad S., McCabe S. \& Smith B.J., 2013 - Algal 'greening' and the conservation of stone heritage structures. Science of the Total Environment, 442: 152-164.

https://doi.org/10.1016/j.scitotenv.2012.10.050

D’ Agostino D., Beccarisi L., Camassa M. \& Febbroriello P., 2015 - Microclimate and microbial characterization in the Zinzulusa show cave (South Italy) after switching to LED lighting. Journal of Cave and Karst Studies, 77 (3): 133-144. https://doi.org/10.4311/2014EX0123

Dakal T. \& Cameotra S., 2012 - Microbially induced deterioration of architectural heritages: routes and mechanisms involved. Environmental Sciences Europe, 24 (36): 1-13.

https://doi.org/10.1186/2190-4715-24-36

Dalby D.H., 1966 - The growth of plants under reduced light. Studies in Speleology, 1 (4): 193-203.

Danin A. \& Caneva G., 1990 - Deterioration of limestone walls in Jerusalem and marble monuments in Rome caused by cyanobacteria and cyanophilous lichens. International Biodeterioration, 26: 397-417.

https://doi.org/10.1016/0265-3036(90)90004-Q

Danon A. \& Gallois P., $1998-U V-C$ radiation induces apoptotic-like changes in Arabidopsis thaliana. FEBS Letters, 437: 131-136. https://doi.org/10.1016/S0014-5793(98)01208-3

Davies D.G., Parsek M.R., Pearson J.P., Iglewski B.H., Costerton J.W. \& Greenberg E.P., 1998 - The involvement of cell to cell signals in the development of a bacterial biofilm. Science, 280: 295-298.

https://doi.org/10.1126/science.280.5361.295

De Muynck W., Ramírez A.M., De Belie N. \& Verstraete W., 2009 - Evaluation of strategies to prevent algal fouling on white architectural and cellular concrete. International Biodeterioration \& Biodegradation, 63: 679-689. https://doi.org/10.1016/j.ibiod.2009.04.007

De Philippis R., Sili C., Paperi R. \& Vincenzini M., 2001 - Exopolysaccharides-producing cyanobacteria and their possible exploitation: a review. Journal of Applied Phycology, 13: 293-299.

https://doi.org/10.1023/A:1017590425924 
De Virville D., 1928 - Influence de la lumière électrique discontinue sur la flore d'une grotte. Mayenne, Laval, Imprimerie Libraire Goupil. France.

De la Torre M.A., Gómez-Alarcón G., Melgarejo P. \& Saiz-Jiménez C., 1991 - Fungi in weathered sandstone from Salamanca Cathedral. Spain. Science of the Total Environment, 107: 159-168. https://doi.org/10.1016/0048-9697(91)90257-F

Del Rosal Y., 2015 - Análisis, impacto y evolución de los biofilms fotosintéticos en espeleotemas. El caso de la Cueva de Nerja. Unpublished Doctoral Thesis, Universidad de Málaga, 336 p.

Del Rosal Y., Roldán M., Liñán C., Garrido A. \& HernándezMariné M., 2012 - Tecnologías de microscopia: una ventana al conocimiento del biodeterioro. In: Durán J.J. \& Robledo P.A. (Eds.), Las cuevas turísticas como activos económicos: conservación e innovación. Asociación de Cuevas Turísticas Españolas, Madrid, p. 359-372.

Delalu H., Peyrot L., Duriche C., Elomar F. \& Elkhatib M., 2001 - Synthesis of enriched solutions of chloramine starting from hypochlorite at high chlorometric degree. Chemical Engineering Journal, 83: 219-224.

https://doi.org/10.1016/S1385-8947(00)00281-3

Di Martino P.D., 2016 - What about biofilms on the surface of stone monuments? The Open Conference Proceedings Journal, 7: 14-28. https://doi.org/10.2174/2210289201607020014

Dobat K., 1963 - Höhlenalgen" bedrohen die Eiszeitmalereien von Lascaux. Die Höhle, 14 (2): 41-45.

Dobat K., 1969 - Die Lampenflora der Barenhöle. In: Wagner G. (Ed.), Die Barenhöle von Erpfingen. Gemeinde Erpfingen, Germany, p. 29-35.

Dobat K., 1970 - Considérations sur la végétation cryptogamique des grottes du Jura Souabe (sud-ouest de l'Allemagne). Annales de Spéléologie, 25 (4): 872-907.

Dornieden T.H., Gorbushina A.A. \& Krumbein W.E., 2000 - Patina-physical and chemical interactions of sub-aerial biofilms with objects of art. In: Ciferri O., Tiano P. \& Mastromei G. (Eds.), Of microbes and art: The role of microbial communities in the degradation and protection of cultural heritage. Kluwer Academic Publishers, Dordrecht, p. 105-119. https://doi.org/10.1007/978-1-4615-4239-1

Drewes J.E. \& Jekel M., 1998 - Behavior of DOV and AOX using advanced treated wastewater for groundwater recharge. Water Resources, 32: 3125-3133.

https://doi.org/10.1016/S0043-1354(98)00064-5

Esteban R., 2014 - Actuaciones para la eliminación del tapiz algal presente en los espeleotemas en la rehabilitación de las grutas visitables de La Paz y de La Viña en Ortigosa de Cameros, La Rioja. Zubía, 32: 7-32.

European Biocides Directive: Directive 98/8/EC of the European Parliament and of the Council of 16 February 1998 concerning the placing of biocidal products on the market L $123 / 124.4 .98$.

Fabbricatore A., 2009 - Grotta Gigante, turismo, ambiente, cultura. Società Alpina delle Giulie, Trieste, Italia, 24 p.

Faimon J., Stelcl J. \& Kubesová S., 2001 - A chemical elimination of "lampflora" in caves. Geological Resesearch in Moravia and Silesia, VIII: 101-103 (in Czech).

Faimon J., Stelcl J., Kubesová S. \& Zimák J., 2003 - Environmentally acceptable effect of hydrogen peroxide on cave "lamp-flora", calcite speleothems and limestones. Environmental Pollution, 122: 417-422. https://doi.org/10.1016/S0269-7491(02)00309-3

Flemming H.C., 1993 - Biofilms and environmental protection. Water Science Technology, 27: 1-10. https://doi.org/10.2166/wst.1993.0528
Garofano M. \& Govoni D., 2012 - Underground Geotourism: a historic and economic overview of show caves and show mines in Italy. Geoheritage, 4: 79-92. https://doi.org/10.1007/s12371-012-0055-3

Garrido A., Liñán C., Simón M.D. \& del Rosal Y., 2007 - Memoria Científica. Fundación Cueva de Nerja 2006. Instituto de Investigación Cueva de Nerja, Málaga, España, 246 p.

Gaylarde P.M. \& Gaylarde C.C., 2000 - Algae and cyanobacteria on painted buildings in Latin America. International Biodeterioration \& Biodegradation, 46: 93-97.

https://doi.org/10.1016/S0964-8305(00)00074-3

Gillieson D.S., 1996 - Caves: processes, development, and management. Blackwell Publishers, Oxford, 324 p.

Gillieson D.S., 2011 - Management of caves. In: Van Beynen P.E. (Ed.), Karst Management. Springer, Dordrecht, p.141-158.

https://doi.org/10.1007/978-94-007-1207-2

Giordano M., Mobili F., Pezzoni V., Hein M.K. \& Davis J.S., 2001 - Photosynthesis in the caves of Frasassi (Italy). Phycologia, 39 (5): 384-389.

https://doi.org/10.2216/i0031-8884-39-5-384.1

Gladis-Schmacka F., Glatzel S., Karsten U., Böttcher H. \& Schumann R., 2014 - Influence of local climate and climate change on aeroterrestrial phototrophic biofilms, Biofouling. The Journal of Bioadhesion and Biofilm Research, 30 (4): 401-414. https://doi.org/10.1080/08927014.2013.878334

Glime J.M., 2007 - Bryophyte ecology Vol. 1: physiological ecology. Michigan Technological University and the International Association of Bryologists, Houghton, https://digitalcommons.mtu.edu/bryophyte-ecology/

Golubic S., Friedmann E.I. \& Schneider J., 1981 - The lithobiontinc ecological niche, with special reference to microorganisms. Journal of Sedimentary Petrology, 51: 475-478.

Golubic S. \& Schneider J., 2003 - Microbial endolith as internal biofilms. In: Kurmbein W.E., Dornieden T.H., Volkmann M., Paterson D.M. \& Zavarzin G.A. (Eds.), Fossil and recent biofilms. A natural history of life on earth. Kluwer Academic Publishers, Dordrecht, p. 249-263. https://doi.org/10.1007/978-94-017-0193-8

Greenwood N.N. \& Aernshaw A., 1984 - Chemistry of the elements. Pergamon Press, Oxford, $1542 \mathrm{p}$.

https://doi.org/10.1016/C2009-0-30414-6

Grobbelaar J.U., 2000 - Lithophytic algae: A major threat to the karst formation of show caves. Journal of Applied Phycology, 12: 309-315. https://doi.org/10.1023/A:1008172227611

Guillitte O., 1995 - Bioreceptivity: a new concept for building ecology studies. Science of Total Environment, 167: 215-220. https://doi.org/10.1016/0048-9697(95)04582-L

Gurnee J., 1994 - Management of some unusual features in the show caves in the United States. International Journal of Speleology, 23 (1-2): 13-17.

https://doi.org/10.5038/1827-806x.23.1.2

Hajdu L., 1966 - Algological studies in the cave at Maytas Mount, Budapest, Hungary. International Journal of Speleology, 2: 137-149. https://doi.org/10.5038/1827-806X.2.1.12

Hadrup N. \& Lam H.R., 2014 - Oral toxicity of silver ions, silver nanoparticles and colloidal silver - a review. Regulatory Toxicology and Pharmacology 68 (1): 1-7. https://doi.org/10.1016/j.yrtph.2013.11.002

Harris D., 1981 - The control of nuisance plant growth in Mammoth Cave, Kentucky. Unpublished report to Mammoth Cave National Park, United States of America, 20 p. 
Hazslinszky T., 2002 - Übersicht der Lampenflorabekämpfung in Ungarn. In: Hazslinszky T. (Ed.), Proceedings of International Conference on Cave Lighting, 15-17 November. Hungarian Speleological Society, Budapest, p. 41-50.

Heaton T., 1986 - Caves: a tremendous range of energy environments on Earth. National Speleological Society News, 44 (8): 301-304.

Hebelka J., 2014 - Methodology of lampenflora removal in caves accessible for tourists. The cave administration of the Czech Republic, Průhonice, 15 p.

Hernández-Mariné M. \& Roldán M., 2005 - Adherence of hormogonia to substrata is mediated by polysaccharides produced by necridic cells. Algological Studies, 117: 239-249.

https://doi.org/10.1127/1864-1318/2005/0117-0239

Herrera L.K., Arroyave C., Guiamet P., de Saravia S.G. \& Videla H., 2004 - Biodeterioration of peridotite and other constructional materials in a building of the Colombian cultural heritage. International Biodeterioration \& Biodegradation, 54: 135-141. https://doi.org/10.1016/i.ibiod.2004.06.001

Hill C.A. \& Forti P., 1997 - Cave Minerals of the World $\left(2^{\text {nd }}\right.$ Ed.) National Speleological Society, Huntsville, AL, 463 p. http://www.minsocam.org/msa/National SpeleologicalSociety/

Hoffmann L., 1989 - Algae of terrestrial habitats. The Botanical Review, 55: 77-105.

https://doi.org/10.1007/BF02858529

Hoffmann L., 2002 - Caves and other low-light environments: aerophitic photoautotrophic microorganisms. In: Bitton G. (Ed.), Encyclopedia of environmental microbiology. John Wiley \& Sons, New York, p. 835-843. https://doi.org/10.1002/0471263397

Hoyos M., Soler V., Cañaveras J.C., Sánchez-Moral S. \& Sanz-Rubio E., 1998 - Microclimatic characterization of a karstic cave: human impact on micro environmental parameters of a prehistoric rock art cave (Candamo Cave, northern Spain). Environmental Geology, 33 (4): 231-242. https://doi.org/10.1007/s002540050242

Hueck-van der Plas E.H., 1965 - The biodeterioration of materials as a part of hylobiology. Material und Organismen, 1: 5-34.

https://repository.tudelft.nl/view/tno/uuid\% 3Acd2e06b7-2a61-4685-96b9-08a490c6e2c0

Hueck-van der Plas E.H., 1968 - The microbiological deterioration of porous building materials. International Biodeteriorarion Bulletin, 4: 11-28.

Humphreys W.F., 1991 - Experimental re-establishment of pulse-driven populations in a terrestrial troglobite community. Journal of Animal Ecology, 60: 609-623. https://doi.org/10.2307/5301

Iliopoulou-Georgoudaki J., Pantazidou A. \& Theoulakis P., 1993 - An assessment of cleaning photoautotropic microflora: The case of "Perama" cave, Ioannina, Greece. Mémoires de Biospéologie, 20: 117-120.

Imprescia U. \& Muzi F., 1984 - Light sources and the flora growth in caves illuminated for touristic purposes. In: Hazslinszky T. (Ed.), International Colloquium on Lamp Flora, 10-13 October, Magyar Karszt. Barlangkutató Tarsulat, Budapest, Hungary, p. 103-113.

Jayakumar M., Eyini M., Selvinthangadurai P., Lingakumar K., Premkumar A. \& Kulandaivelu G., 1999 - Changes in pigment composition and photosynthetic activity of aquatic fern (Azolla microphylla) exposed to low doses of $U V-C(254 \mathrm{~nm})$ radiation. Photosynthetica, 37: 33-38. https://doi.org/10.1023/A:1007010727978

Johnson K., 1979 - Control of Lampenflora at Waitomo Caves, New Zealand. In: Robinson A.A. (Ed.), Cave
Management in Australia III. Proceedings of the 3rd Australasian Cave Tourism and Management Conference. South Australian National Parks and Australian Speleological Federation, Adelaide, p. 105122. http://www.ackma.org/papers/Wait3.html

Jones M.V., 1995 - Fungal biofilms; eradication of a common problem. In: Wimpenny J., Handley P., Gilbert P. \& Lappin-Scott H.M. (Eds.), The life and death of biofilm. Bioline, Cardiff, p. 157-160.

Jordá Pardo J.F., Maestro González A., Aura Tortosa J.E., Álvarez Fernández E., Avezuela Aristu B., Badal García E., Morales Pérez J.V., Pérez Ripio M. \& Villalba Currás M.P., 2011 - Evolución paleogeográfica, paleoclimática y paleoambiental de la costa meridional de la Península Ibérica durante el Pleistoceno superior. El caso de la Cueva de Nerja (Málaga, Andalucia, España). Boletín de la Real Sociedad Española de Historia Natural, Sectión Geologica, 105 (1-4): 137-147. http://roderic.uv.es/handle/10550/27929

Jurado V., Porca E. \& Saiz-Jiménez C., 2010 - Control de un brote fúngico en la Cueva de Castañar de Ibor. In: Durán J.J. \& Carrasco F. (Eds.), Cuevas: Patrimonio, Naturaleza, Cultura y Turismo. Asociación de Cuevas Turísticas Españolas (ACTE). Madrid, p. 611-620. http://hdl.handle.net/10261/130592

Jurado V., Hernández-Mariné M., Rogerio-Candelera M.A., Domínguez-Moñino I., Gutiérrez-Patricio S. \& Saiz-Jiménez C., 2014 - La Cueva del Tesoro: un paraíso microbiano. In: Calaforra J.M. \& Durán J.J. (Eds.), Cuevatur 2014. Primer Congreso Iberoamericano y Quinto Congreso Español sobre Cuevas Turísticas. Asociación de Cuevas Turísticas Españolas (ACTE), Aracena, p. 433-441. http://hdl.handle.net/10261/116312

Jurado V. \& Saiz-Jiménez C., 2016 - Vida microbiana en las cavernas: el fascinante mundo de la biodiversidad subterránea y su papel en los procesos de deterioro. Enseñanza de las Ciencias de la Tierra, 24 (1): 51-60.

Karsten U., Schumann R. \& Mostaert A.S., 2007 Aeroterrestrial algae growing on man-made surfaces. In: Seckbach J. (Ed.), Algae and cyanobacteria in extreme environments. Springer, Dordrecht, p. 585-597. https://doi.org/10.1007/978-1-4020-6112-7_32

Kartalis N. \& Mais K., 2001 - The influence of illumination in the Alistrati Cave, Serron, NE Greece. In: Hazslinszky T. (Ed.), Proceedings of International Conference on Cave Lighting, 15-17 November. Hungarian Speleological Society, Budapest, p. 65

Kermode L., 1975 - Glow-worm Cave Waitomo conservation study. New Zealand Speleological Bulletin, 5 (91): 329-344.

Khanjani M., Zahiri B., Fayaz B.A. \& Khedri S.J., 2014 - Efficient hydrogen peroxide concentration against lampenflora (Mosses) in Ali-Saddr Cave. In: Zhalov A., Ivanov I. \& Petrov I. (Eds.), Proceedings of Balkan Speleological Conference "Sofia-2014". European Speleological Federation, Bulgaria, p. 98-99.

Kol E., 1967 - Algal growth experiments in the Baradla Cave at Aggtelek. International Journal of Speleology, 2: 457-474.

https://doi.org/10.5038/1827-806X.2.4.18

Korber D.R., James G.A. \& Costerton J.W., 1994 Evaluation of fleroxacin activity against established Pseudomonas fluorescens biofilms. Applied and Environmental Microbiology, 60: 1663-1669.

Krumbein W.E., 1988 - Microbial interactions with mineral materials. In: Houghton D.R., Smith R.N. \& Eggins H.O.W. (Eds.), Biodeterioration. Elsevier, London, p.78100. https://doi.org/10.1007/978-94-009-1363-9_11 
Kubesová S., Faimon J., Stelcl J. \& Zimák J., 2000 The study of lampflora in the Katerinská Cave. In: Hazslinszky T. (Ed.), Proceedings of International Conference on Cave Lighting, 15-17 November. Hungarian Speleological Society, Budapest, p. 14-15.

Kumar C.G. \& Anand S.K., 1998 - Significance of microbial biofilms in food industry: a review. International Journal of Food Microbiology, 42: 9-27. https://doi.org/10.1016/s0168-1605(98)00060-9

Kumar R. \& Kumar A.V., 1999 - Biodeterioration of stone in tropical environments: An overview. Getty Conservation Institute, Los Angeles, $85 \mathrm{p}$.

Kyrle G., 1923 - Grundgriss der theoretischen Speläologie. Österreichischen Staatsdruckerei, Wien, 353 p

Lawrence J.R., Korber D.R., Hoyle B.D., Costerton J.W. \& Caldwell D.E., 1991 - Optical sectioning of microbial biofilms. Journal of Bacteriology, 173: 6558-6567. https:// doi.org/ 10.1128/jb.173.20.6558-6567.1991

Lefèvre M., 1974 - La "maladie verte" de Lascaux. Studies in Conservation, 19: 126-156.

https://doi.org/10.2307/1505660

Martín-Sánchez P.M., 2012 - Las manchas negras de la cueva de Lascaux: origen, evolución y caracterización de un brote fúngico. Unpublished Doctoral Thesis, Universidad de Sevilla, 266 p. http://hdl.handle.net/10261/61914

Martincic A., Vrhovšek D. \& Batic F., 1981 - Flora in caves with artificial lights in Slovenia. Biološki vestnik, 29 (2): 27-56.

Martinez A. \& Asencio A.D., 2010 - Distribution of Cyanobacteria at the Gelada Cave (Spain) by physical parameters. Journal of Cave and Karst Studies, 72: 11-20. https://doi.org/10.4311/jcks20091sc0082

Merdenisianos C., 2005 - The maladie verte (green disease) of the caves. Proceedings of the $14^{\text {th }}$ International Congress of Speleology, 21-28 August, Athens-Kalamos, Greece, p. 160-162.

Meyer E., Seale L.D., Permar B. \& MacClary A., 2017 The Effect of Chemical Treatments on lampenflora and a Collembola indicator species at a popular tour cave in California, USA. Environmental Management, 59 (6): 1034-1042. https://doi.org/10.1007/s00267-017-0842-3

Miller A.Z., Dionísio A., Laiz L., Macedo M.F. \& SaizJiménez C., 2009 - The influence of inherent properties of building limestones on their bioreceptivity to phototrophic microorganisms. Annals of Microbiology, 59: 705-713. https://doi.org/10.1007/BF03179212

Miller A.Z., Sanmartín P., Pereira -Pardo L., Dionísio A., Saiz-Jiménez C., Macedo M.F. \& Prieto B., 2012 Bioreceptivity of building stones: a review. Science of the Total Environment, 426: 1-12.

https://doi.org/10.1016/j.scitotenv.2012.03.026

Moharikar S., D'Souza J.S., Kulkarni A.B. \& Rao B.J., 2006 - Apoptotic-like cell death pathway is induced in unicellular chlorophyte Chlamydomonas reinhardtii (Chlorophyceae) cells following UV irradiation: detection and functional analyses. Journal of Phycology, 42: 423-433.

https://doi.org/10.1111/j.1529-8817.2006.00207.x

Montechiaro F. \& Giordano M., 2006 - Effect of prolonged dark incubation on pigments and photosynthesis of the cave-dwelling cyanobacterium Phormidium autumnale (Oscillatoriales, Cyanobacteria). Phycologia, 45 (6): 704-710. https://doi.org/10.2216/06-15.1

Morton F. \& Gams H., 1925 - Höhlenpflanzen. Verlag Eduard Hölzel, Wien, 227 p.

Mulec J., 2005 - Algae in the karst caves of Slovenia. Unpublished Doctoral Thesis, University of Ljubljana, 149 p.
Mulec J., 2012 - Lampenflora. In: White W.B. \& Culver D.C. (Eds.), Encyclopedia of caves. Elsevier, Amsterdam, p. 451-456. https://doi.org/10.1016/C2010-0-64793-6

Mulec J., 2014 - Human impact on underground cultural and natural heritage sites, biological parameters of monitoring and remediation actions for insensitive surfaces: Case of Slovenian show caves. Journal for Nature Conservation, 22: 132-141.

https://doi.org/10.1016/j.jnc.2013.10.001

Mulec J., Kosi G. \& Vrhovšek D., 2008 - Characterization of cave aerophytic algal communities and effects of irradiance levels on production of pigments. Journal of Cave and Karst Studies, 70 (1): 3-12. http://ww.caves. org/pub/journal/PDF/v70/cave-70-01-3.pdf

Mulec J. \& Kosi G., 2009 - Lampenflora algae and methods of growth control. Journal of Cave and Karst Studies, $\mathbf{7 1}$ (2): 109-115.

https://caves.org/pub/journal/PDF/v71/cave-71-02109.pdf

Mulec J. \& Glažar S., 2011 - First results on use of a hydrogen peroxide solution in Postojnska jama (Slovenia) to remove lampenflora. In: Bella P. \& Gazik P. (Eds.), Proceedings of the $6^{\text {th }}$ ISCA Congress. Slovak Caves Administration, p. 128-131.

Newbould R.L., 1974 - Steam cleaning of orient cave, Jenolan Caves. Jenolan Caves Historical \& Preservation Society, New South Wales, Australia, 17 p.

Nikolaev Y.A. \& Plakunov V.K., 2007 - Biofilm, "City of microbes" or an analogue of multicellular organisms? Microbiology, 76: 125-138.

https://doi.org/10.1134/S0026261707020014

Nugari M.P., Pietrini A.M., Caneva G., Imperi F. \& Visca P., 2009 - Biodeterioration of mural paintings in a rocky habitat: the Crypt of the original Sin (Matera, Italy). International Biodeterioration \& Biodegradation, 63: 705-711.

https://doi.org/10.1016/j.ibiod.2009.03.013

Nuhoglu Y., Oguz E., Uslu H., Ozbek A., Ipekoglu B., Ocak I. \& Hasenekoglu I., 2006 - The accelerating effects of the microorganisms on biodeterioration of stone monuments under air pollution and continental cold climatic conditions in Erzurum, Turkey. Science of the Total Environment, 364: 272-283.

https://doi.org/10.1016/j.scitotenv.2005.06.034

Olson R., 2002 - Control of lamp flora in Mammoth Cave National Park. In: Hazslinszky T. (Ed.), Proceedings of International Conference on Cave Lighting, 15-17 November. Hungarian Speleological Society, Budapest, p. 31-36.

Olson R., 2006 - Control of lamp flora in developed caves. In: Hildreth-Werker V. \& Werker J.C. (Eds.), Cave conservation and restoration. National Speleological Society, Huntsville, p. 343-348.

Oostthuizen H., 1981 - The blue -green algae in the Cango Cave System. In: Mylroie J. (Ed.), Proceedings $1^{\text {st }}$ International Cave Management Symposium. Murray State University, Murray, 153 p.

Orial G., Bousta F., François A., Pallot-Frossard I. \& Warscheid T., 2009 - Gestion des activités biologiques à Lascaux: identification des microorganismes, contrôles et traitements. LBW Bioconsult LRMH, France, 29 p. http://www.lrmh.fr/IMG/pdf/par-2009-2-219preprints.pdf

Ortega-Calvo J.J., Hernández-Mariné M. \& SaizJiménez C., 1991 - Biodeterioration of building materials by cyanobacteria and algae. International Biodeterioration, 28: 165-185.

https://doi.org/10.1016/0265-3036(91)90041-O 
Ou H., Gao N., Deng Y., Wang H. \& Zhang H., 2011 Inactivation and degradation of Microcystis aeruginosa by UV -C irradiation. Chemosphere, 85: 1192-1198. https://doi.org/10.1016/j.chemosphere.2011.07.062

Ou H., Gao N., Deng Y., Qiao J. \& Wang H., 2012 Immediate and long-term impacts of $U V-C$ irradiation on photosynthetic capacity, survival and microcystin-LR release risk of Microcystis aeruginosa. Water Research, 46: 1241-1250.

https://doi.org/10.1016/j.watres.2011.12.025

OxyChem (2014) Sodium Hypochlorite. Handbook, 25 p. https://www.oxy.com/OurBusinesses/Chemicals/ Products/Documents/sodiumhypochlorite/bleach.pdf

Padisàk J., Rajczy M., Paricsy-Komaromy Z. \& Hazslinszky T., 1984 - Experiments on algae and mosses developing around different lamps in the cave "Pal-Völgyi-Barlang". In: Hazslinszky T. (Ed.), International Colloquium on Lamp Flora, 10-13 October. Barlangkutató Tarsulat, Budapest, p. 83-102.

Papida S., Murphy W. \& May E., 2000 - Enhancement of physical weathering of building stones by microbial populations. International Biodeterioration \& Biodegradation, 46: 305-317.

https://doi.org/10.1016/S0964-8305(00)00102-5

Peraza-Zurita Y., Cultrone G., Sánchez-Castillo P., Sebastián E. \& Bolivar F.C., 2005 - Microalgae associated with deteriorated stonework of the fountain of Bibatauin in Granada, Spain. International Biodeterioration \& Biodegradation, 55: 55-61. https://doi.org/10.1016/j.ibiod.2004.05.006

Perry T.D., Duckworth O.W. \& McNamara C.J., 2004 - Effects of the biologically produced polymer alginic acid on macroscopic and microscopic calcite dissolution rates. Environmental Science of Technology, 38: 30403046. https://doi.org/10.1021/es035299a

Pfendler S., Borderie F., Bousta F., Alaoui-Sossea L., Alaoui-Sosse B. \& Aleya L., 2018 - Comparison of biocides, allelopathic substances and UV-Cas treatments for biofilm proliferation on heritage monuments. Journal of Cultural Heritage, 33: 117-124.

https://doi.org/10.1016/j.culher.2018.03.016

Pinna D., Salvadori B. \& Galleotti M., 2012 - Monitoring the performance of innovative and traditional biocides mixed with consolidants and water-repellents for the prevention of biological growth on stone. Science of the Total Environment, 423: 132-141.

https://doi.org/10.1016/j.scitotenv.2012.02.012

Planina T., 1974 - Prevent the growth of vegetation at the lights of tourist caves. Nase Jame, 16: 31-35.

Porca E., Jurado V., Martín-Sánchez P.M., Hermosin B., Bastian F., Alabouvette C. \& Saiz-Jiménez C., 2011 Aerobiology: An ecological indicator for early detection and control of fungal outbreaks in caves. Ecological Indicators, 11: 1594-1598.

https://doi.org/10.1016/j.ecolind.2011.04.003

Potts M., 1999 - Mechanisms of desiccation tolerance in cyanobacteria. European Journal of Phycology, 34: 319-328.

https://doi.org/10.1080/09670269910001736382

Potts M., 2001 - Desiccation tolerance: a simple process?. Trends in Microbiology, 9: 553-559.

https://doi.org/10.1016/S0966-842X(01)02231-4

Prakash B., Veeregowda B.M. \& Krishnappa G., 2003 - Biofilms: A survival strategy of bacteria. Current Science, 85: 1299-1307.

https://pdfs.semanticscholar.org/c7bf/1c4e0d0dc94 46f5481c576d69023338d44d1.pdf

Pulido-Bosch A., Martín-Rosales W., López-Chicano M., Rodríguez-Navarro C.M. \& Vallejos A., 1997 - Human impact in a tourist karstic cave (Aracena, Spain). Environmental Geology, 31: 142-149.

https://doi.org/10.1007/s002540050173

Ragon M., 2011 - Diversité et processus de colonisation microbienne dans des biofilms sur des substrats minéraux. Unpublished Doctoral Thesis, Université de Paris-Sud, 200 p.

Raymond F., Hamilton Jr., Nianqiang Wu., Dale Porter., Mary Buford., Michael Wolfarth. \& Holian A., 2009 - Particle length-dependent titanium dioxide nanomaterials toxicity and bioactivity. Particle and Fiber Toxicology, 6: 35.

https://doi.org/10.1186/1743-8977-6-35

Rajczy M., 1989 - The flora of Hungarian caves. Karszt és Barlang, Special issue, 69-72.

https://epa.oszk.hu/02900/02993/00044/pdf/ EPA02993_karszt_es_barlang_1989_SI_069-071.pdf

Rajczy M., Buczko K. \& Hazslinszky T., 1997 - Efforts for the restriction of lamp flora: Results and experiences between 1984 and 1996. In: Toth E. \& Horvath R. (Eds.), Proceedings of the "Research, Conservation, Management" Conference. Aggtelek National Park Directorate, Aggtelek, Hungary, 54 p.

Ramírez M., Hernández-Mariné M., Mateo P., Berrendero E. \& Roldán M., 2011 - Polyphasic approach and adaptative strategies of Nostoc cf. commune (Nostocales, Nostocaceae) growing on Mayan monuments. Fottea 11 (1): 73-86. https://doi.org/10.5507/fot.2011.008

Ramírez-Trillo F. \& González-Ríos M.J., 2014 - Cueva de las Ventanas. 14 años de experiencias del mal verde $y$ criterios para una nueva iluminación con diodos leds. In: Calaforra J.M. \& Durán J.J. (Eds.), Cuevatur 2014. Primer Congreso Iberoamericano y Quinto Congreso Español sobre Cuevas Turísticas. Asociación de Cuevas Turísticas Españolas (ACTE), Aracena, p. 475-485.

Roldán M., Clavero E., Canals T., Gómez-Bolea A., Ariño X. \& Hernández-Mariné M., 2004 - Distribuiton of phototrophic biofilms in cavities (Garraf, Spain). Nova Hedwigia, 78: 329-351.

https://doi.org/10.1127/0029-5035/2004/0078-0329

Roldán M., Oliva F., Gónzalez Del Valle M.A., SaizJiménez C. \& Hernández-Mariné M., 2006 - Does green light influence the fluorescence properties and structure of phototrophic biofilms? Applied and Environmental Microbiology, 72: 3026-3031.

https://doi.org/10.1128/AEM.72.4.3026-3031.2006

Roldán M. \& Hernández-Mariné M., 2009 - Exploring the secrets of the three-dimensional architecture of phototrophic biofilms in caves. International Journal of Speleology, 38 (1): 41-53. https://doi.org/10.5038/1827-806X.38.1.5

Ruffolo S.A., De Leo F., Ricca M., Arcudi A., Silvestri C., Bruno L., Urzì C. \& La Russa M.F., 2017 -Medium-term in situ experiment by using organic biocides and titanium dioxide for the mitigation of microbial colonization on stone surfaces. International Biodeterioration \& Biodegradation, 123: 17-26. https://doi.org/10.1016/j.ibiod.2017.05.016

Saiz-Jiménez C., 1994. Biodeterioration of stone in historic building and monuments. In: Llewellyn G.C., Dashek W.W. \& O`Read C.E. (Eds.), Biodeterioration research 4: Mycotoxins, wood decay, plants stress, biocorrosion, and general biodeterioration. Plenum, New York, p. 587-603.

https://doi.org/10.1007/978-1-4757-9450-2_45

Saiz-Jiménez C., 1999 - Biogeochemistry of weathering processes in monuments. Geomicrobioly Journal, 16: 27-37.

https://doi.org/10.1080/014904599270721 
Saiz-Jiménez C., 2012 - Microbiological and environmental issues in show caves. World Journal of Microbiology and Biotechnology, 28: 2453-2464. https://doi.org/10.1007/s11274-012-1070-x

Saiz-Jiménez C., Cuezva S., Jurado V., FernándezCortes A., Porca E., Benavente D., Cañaveras J.C. \& Sánchez-Moral S., 2011 - Paleolithic art in peril: Policy and science collide at Altamira Cave. Science, 333: 42-43. https://doi.org/10.1126/science.1206788

Sarró M.I., García A.M., Rivalta V.M., Moreno D.A. \& Arroyo I., 2006 - Biodeterioration of the lions fountain at the Alhambra Palace, Granada (Spain). Building and Environment, 41: 1811-1820.

https://doi.org/10.1016/j.buildenv.2005.07.029

Sakai H., Oguma K., Katayama H. \& Ohgaki S., 2007 - Effects of low-or medium-pressure ultraviolet lamp irradiation on Microcystis aeruginosa and Anabaena variabilis. Water Resources, 41: 11-18. https://doi.org/10.1016/j.watres.2006.09.025

Scheerer S., Ortega-Morales O. \& Gaylarde C., 2009 Chapter 5: microbial deterioration of stone monuments, an updated overview. In: Laskin A., Sariaslani S. \& Gadd G.M. (Eds.), Advances in applied microbiology. Academic, Washington D.C., p. 97-139. https://doi.org/10.1016/S0065-2164(08)00805-8

Sharif D.I., Gallon J., Smith C.J. \& Dudley E., 2008 - Quorum sensing in Cyanobacteria: N-octanoylhomoserine lactone release and response, by the epilithic colonial cyanobacterium Gloeothece PCC6909. The ISME Journal, 2: 1171-1182. https://doi.org/10.1038/ismej.2008.68

Sierra-Fernández A., Gómez-Villalba L.S., Rabanal M.E. \& Fort R., 2017 - New nanomaterials for applications in conservation and restoration of stony materials: A review. Materiales de la Construccion, 67: 325 http://materconstrucc.revistas.csic.es/index.php/ materconstrucc/article/view/2161

Simon K.S., Pipan T. \& Culver D.C., 2007 - A conceptual model of the flow and distribution of organic carbon in caves. Journal of Cave and Karst Studies, 69 (2): 279284. http://w.caves.org/pub/journal/PDF/v69/cave69-02-279.pdf

Simon K.S., 2012 - Cave ecosystems. In: White W.B. \& Culver D.C. (Eds.), Encyclopedia of caves. Elsevier, Amsterdam, p. 99-102.

https://doi.org/10.1016/C2010-0-64793-6

Singh S.P., Kumari S., Rastogi R.P., Singh K.L. \& Sinha R.P., 2008 - Mycosporines-like amino acids (MAAs): chemical structure, biosynthesis and significance as UV-absourbing/screening compounds. Indian Journal of Experimental Biology, 46: 7-17.

https://pdfs.semanticscholar.org/2b65/f0548367e96 aa4da9750c37657c0c0f84bdd.pdf

Smith T. \& Olson R., 2007 - A taxonomic survey of Lamp Flora (Algae and Cyanobacteria) in electrically lit passages within Mammoth Cave National Park, Kentucky. International Journal of Speleology, 36 (2): 105-114. https://doi.org/10.5038/1827-806X.36.2.6

Spate A. \& Moses C., 1994 - Impacts of high pressure cleaning a case study at Jenolan. Cave Management in Australasia, 10: 45-48.

http://www.ackma.org/Proceedings/proceed/10/ wash.html

Sasso S., Miller A.Z., Rogerio-Candelera M.A., Cubero B., Coutinho M.L., Scrano L. \& Bufo S.A., 2016 - Potential of natural biocides for biocontrolling phototrophic colonization on limestone. International Biodeterioration \& Biodegradation, 107: 102-110.

https://doi.org/10.1016/j.ibiod.2015.11.017
Steiger M., Wolf F. \& Dannecker W., 1993 - Deposition and enrichment of atmospheric pollutants on building stones as determined by field exposure experiments. In: Thiel M.J. (Ed.), Conservation of stone and other materials, Vol. 1. E. \& F.N. Spon publisher., London, p. $32-42$

Stupar M., Grbić M.L.J., Džamic A., Unković N., Ristić M., Jelikić A. \& Vukojević J., 2014 - Antifungal activity of selected essential oils and biocide benzalkonium chloride against the fungi isolated from cultural heritage objects. South African Journal of Botany, 93: 118-124. https://doi.org/10.1016/j.sajb.2014.03.016

Tao Y., Zhang X., Au D.W.T., Mao X. \& Yuan K., 2010 - The effects of sublethal UV-C irradiation on growth and cell integrity of cyanobacteria and green algae. Chemosphere, 78: 541-547.

https://doi.org/10.1016/j.chemosphere.2009.11.016

Tao Y., Mao X., Hu J., Mok H., Wang L., Au D., Zhu J. \& Zhang X., 2013 - Mechanisms of photosynthetic inactivation on growth suppression of Microcystis aeruginosa under UV-C stress. Chemosphere, 93: 637-644.

https://doi.org/10.1016/j.chemosphere.2013.06.031

Toomey R.S., Olson R., Kovar S., Adams M. \& Ward R.H., 2009 - Relighting Mammoth Cave's new entrance: improving visitor experience, reducing exotic plant growth, and easing maintenance. In: White W.B. (Ed.), Proceedings of the $15^{\text {th }}$ International Congress of Speleology, Kerrville, Texas, 2: 1223-1228.

http://www.uis-speleo.org/ics/15th proceedingsv002.pdf

Trinh D.A., Trinh Q.H., Tran N., Guinea J.G. \& Mattey D., 2018 - Eco-friendly remediation of lampenflora on speleothems in tropical karst caves. Journal of Cave and Karst Studies, 80 (1): 1-12

https://doi.org/10.4311/2017ES0101

Trinh D.A. \& García J., 2013 - Vulnerability, pressures, and protection of karst caves and their speleothems in Ha Long Bay, Vietnam. Environmental Earth Sciences, 71: 4899-4913. https://doi.org/10.1007/s12665-013-2884-Z

Urzi C., De Leo F., Bruno L. \& Albertano P., 2010 Microbial diversity in Paleolithic caves: a study case on the phototrophic biofilms of the Cave of Bats (Zuheros, Spain). Microbial Ecology, 60: 116-129. https://doi.org/10.1007/s00248-010-9710-x

Van Der Molen J.M., Garty J., Aardema B.W. \& Krumbein W.E., 1980 - Growth control of algae and cyanobacteria on historical monuments by a mobile UV unit (MUVU). Studies in Conservation, 25: 71-77. https://doi.org/10.2307/1505862

Vegh Z., 1989 - The problem of the lampflora in Baradla cave. Proceedings of the $10^{\text {th }}$ International Congress of Speleology, Budapest, p. 559-561.

Wakefield R.D. \& Jones M.S., 1998 - An introduction to stone colonizing micro-organisms and biodeterioration of building stone. Quarterly Journal of Engineering Geology and Hydrogeology, 31: 301-313.

https://doi.org/10.1144/GSL.QJEG.1998.031.P4.03

Warscheid T. \& Braams J., 2000 - Biodeterioration of stone: a review. International Biodeterioration \& Biodegradation, 46: 343-368.

https://doi.org/10.1016/S0964-8305(00)00109-8

Watnick P. \& Kolter R., 2000 - Biofilm, city of microbes. Journal of Bacteriology, 182: 2675-2679.

https://doi.org/10.1128/JB.182.10.2675-2679.2000

Watson J., Hamilton-Smith E., Gillieson D. \& Kiernan K., 1997 - Guidelines of cave and karst protection. IUCN, Gland, Switzerland and Cambridge U.K., 53 p. https://portals.iucn.org/library/sites/library/files/ documents/1997-026.pdf 
Werker J.C. \& Hildreth-Werker V., 2004 - Restoration of caves and speleothem repair. In: Gunn J. (Ed.), Encyclopedia of caves and karst science. Taylor and Francis, New York, p. 1335-1340. https://doi.org/10.4324/9780203483855

Whitton B.A. \& Potts M., 2000 - The ecology of cyanobacteria: Their diversity in time and space. Kluwer Academic Publishers, Dordrecht, $669 \mathrm{p}$. https://doi.org/10.1007/0-306-46855-7

UNESCO - https://whc.unesco.org/ [accessed: March 7, 2011].

Union Internationale de Spéléologie - https://www.uisspeleo.org/ [accessed: March 7, 2019].

Yin R., Dai T., Avci P., Jorge A.E., de Melo W.C., Vecchio D., Huang Y.Y., Gupta A. \& Hamblin M.R., 2013 Light based anti-infectives: ultraviolet $C$ irradiation, photodynamic therapy, blue light, and beyond. Current Opinion in Pharmacology, 13: 731-762.

https://doi.org/10.1016/j.coph.2013.08.009
Wierzchos J., Ascaso C. \& McKay C.P., 2006 - Endolithic cyanobacteria in halite rocks from the hyperarid core of the Atacama Desert. Astrobiology, 6: 415-422. https://doi.org/10.1089/ast.2006.6.415

Zarzuela R., Moreno-Garrido I., Blasco J., Gil M.L.A. \& Mosquera M.J., 2018 - Evaluation of the effectiveness of $\mathrm{CuONPS} / \mathrm{SiO}_{2}$-based treatments for building stones against the growth of phototrophic microorganisms. Construction and Building Materials, 187: 501-509. https://doi.org/10.1016/j.conbuildmat.2018.07.116

Zelinka J., Hebelka J., Fillo M. \& Novomesky J., 2002 Illumination reconstruction in Slovakian show caves in relation to "lampflora" creation prevention. In: Hazslinszky T. (Ed.), Proceedings of International Conference on Cave Lighting, 15-17 November. Budapest, p. 151-157.

Zvezdanović J., CvetićT., Veljović-JovanovićS. \& Marković D., 2009 - Chlorophyll bleaching by UV-irradiation in vitro and in situ: absorption and fluorescence studies. Radiation Physics and Chemistry, 78: 25-32. https://doi.org/10.1016/j.radphyschem.2008.07.006 